\title{
UN IMPUESTO SINGULAR: EL DIEZMO-SEÑOR Y LA SAL EN AÑANA, SIGLOS XVI-XIX
}

\section{RoSARIO PORRES MARIJUÁN}

Universidad del País Vasco

RESUMEN: Cuando a partir de 1564 las salinas de Añana comenzaron a producir para la Corona, sus propietarios se vieron obligados a pagar al rey un tributo anual por el uso de las mueras, admitidas como un ius regalia de la monarquía: el diezmoseñor. Desde entonces, todo el entramado de la fabricación y venta de la sal se organizó en torno a él. En este artículo se analizan algunas de las características de este canon tan singular que se mantuvo en vigor hasta el siglo $X X$.

Palabras Clave: Sal. Salinas. Añana. Diezmo. Situado. Corona. Desamortización.

ABSTRACT: When from 1564 onwards the saltworks of Añana started to produce for the Crown, their owners were forced to pay the king an annual tribute for the use of the brines admitted as an ius regalia of the monarchy: the diezmo-señor or tenth. From that moment onwards, everything concerning with the making and sale of salt was organised around it. In this article, some of the characteristics of this unusual levy which survived until till the XXth Century will be analysed.

KEY WORDS: Salt. Saltworks. Añana. Tithe. Crown. Tenth alienation.

La ley 10 de agosto de 1564 por la que Felipe II declaró incorporadas las salinas del reino de Castilla al patrimonio real, vino a ser el broche al difícil proceso

\section{ABREVIATURAS UTILIZADAS:}

ATHA. Archivo del Territorio Histórico de Álava;

AHPA. Archivo Histórico Provincial de Álava;

AHN. Archivo Histórico Nacional;

ARCHV. Archivo de la Real Chancillería de Valladolid;

AGS. Archivo General de Simancas. 
de homogeneización del comercio de la sal que los monarcas venían intentando desde la Edad Media. Con ella se ponía en marcha el sistema de estanco, que reservaba para la Corona el monopolio de la fabricación y la venta de la sal. No era la primera vez que así sucedía, sólo que ahora el entramado habría de mantenerse en vigor durante tres siglos. Se pretendían varias cosas a un tiempo. En primer lugar, agilizar la comercialización y poner fin a los serios problemas que el anterior régimen anterior de límites y guías provocaba, declarando la libre circulación de la sal en el reino. En segundo lugar, alcanzar una mayor regularidad en el abasto y en el precio, al establecer uno más homogéneo y elevado que pudiera proporcionar unos recursos más dilatados al erario real. Salvo raras excepciones, la producción de las salinas expropiadas pasó a venderse a un precio uniforme de seis reales por fanega en la salina lo que, al mismo tiempo, permitió conocer de antemano el precio que se podía pedir por la renta ${ }^{1}$.

Las salinas alavesas de Añana, consideradas entre las más importantes del norte peninsular junto con las de Poza, fueron incorporadas entonces, aunque los derechos de los antiguos propietarios fueron respetados. Se contaban entre ellos, además de numerosos vecinos de la villa, diversos monasterios burgaleses, alaveses y riojanos, que habían ido adquiriendo sus eras desde el siglo IX a través de sucesivas donaciones, ya de los señores de la zona, ya del monarca ${ }^{2}$. También algunas instituciones laicas como el Hospital del Rey de Burgos poseían eras en la localidad alavesa, fruto a buen seguro de sucesivas concesiones regias, tan frecuentes como fueron desde la primera mitad del siglo XIII las donaciones reales de rentas situadas sobre las salinas o cantidades de sal a favor de instituciones religiosas y hospitales en todo el obispado de Burgos ${ }^{3}$. De igual modo los Sarmiento, condes de Salinas desde mediados del siglo XV, a quienes el rey, que se había reservado para sí las salinas cuando la villa de Añana se señorializó al ser entregada a aquel linaje en $1391^{4}$, les concedió sus rentas en 1464 por juro de

1 UlloA, Modesto: La Hacienda Real en Castilla en el reinado de Felipe II, Madrid, 1977, pág. 385.

2 Lopez Castillo, Santiago: Diplomatario de Salinas de Añana, 1194-1465, San Sebastián, 1984, págs. 1-4. Entre los más importantes cabe destacar: los burgaleses San Pedro de Cardeña, San Pedro de Arlanza, Abadía de Covarrubias, San Salvador de Oña, Santo Domingo de Silos, Santa María la Real de las Huelgas de Burgos, San Juan de Ortega, Santa María de Bujedo, Santa María del Espino, San Miguel del Monte, Santa María la Real de Obarenes, Santa María del Vadillo; Los riojanos San Millán de la Cogolla, Santa María de Valvanera, Santa María la Real de Nájera, Santa María de la Estrella; y entre los alaveses, San Andrés de Armentia, etc.

3 Los más beneficiados fueron Las Huelgas, el Hospital del Rey, Oña, la catedral de Burgos y, en menor medida, Arlanza, Cardeña, Silos, Rioseco, San Juan de Burgos, etc. MARiÑo VeIRAS, Dolores: «Fiscalidad regia y poder feudal en el Obispado de Burgos (1126-1256)», en FERNÁNDEZ DE PINEDO, Emiliano (Editor): Haciendas Forales y Hacienda Real, Bilbao, 1990, pág. 26.

4 Alfonso XI vendió la villa a doña Blanca, hija del infante don Pedro, aunque su hijo Pedro I la devolvió al patrimonio real en 1350. Pero luego Diego Gómez Sarmiento cobró el señorío de la villa en tiempos de Enrique II, tras casar con doña Leonor de Castilla, hija de don Fadrique, maestre de Santiago y hermano del propio rey. Álava vivía entonces un proceso de reseñorialización que se extendió entre los siglos XIV y XV, durante el cual muchas de sus localidades fueron entregadas 
heredad como pago a los servicios realizados por Pero Ruiz Sarmiento y su hijo Diego Gómez, por un precio de 130.000 maravedíes anuales 5 .

Cuando en 1564 llegó el estanco, las salinas de Añana pasaron a funcionar como una fábrica real. Como en las cercanas de Poza y Rosío, en la salina alavesa la Corona pasó a tener sus propias granjas de producción -imposibles de cuantificar hasta el siglo XIX_- pero respetó las que pertenecían a los propietarios particulares asociados en la llamada Comunidad de los Caballeros Herederos de las Salinas a los cuales, eso sí, "compraría» anualmente la producción a fin de asegurar el monopolio regio de venta. Desde entonces los salineros entregaron puntualmente sus cosechas en los tres — más tarde cuatro- almacenes reales construidos en la villa aunque, como venían haciendo desde los tiempos de Alfonso XI, pudieron reservarse cada año ciertas cantidades de sal para el consumo propio, en función del número de componentes del núcleo familiar y sus ganados $^{6}$. En todo caso, la ley de 1564 estableció que los antiguos dueños de las salinas debían ser indemnizados. Que se sepa, el rey indemnizó al conde de Salinas, aunque no podemos calibrar en concepto de qué lo hizo: si por enajenarle eras de su propiedad, o por compensarle de la reincorporación a la Corona de las rentas reales que a mediados del siglo XV se les habían otorgado a sus antepasados, o por ambas cosas a la vez. Sí es cierto que el conde conservó las alcabalas y otros derechos sobre la villa ${ }^{7}$, pero la indemnización por las salinas se le pagó aunque fuera tarde y $\mathrm{mal}^{8}$.

En cambio no se conocen indemnizaciones a otros propietarios, lo que vendría a corroborar que permanecieron en condiciones muy similares a las de antes de la incorporación. Conservaron sus granjas de sal, compuestas por eras

por los reyes de Castilla a algunos de sus vasallos. Los Sarmiento, en la guerra civil castellana entablada entre Pedro I y Enrique II, se contaron en el partido de este último, a consecuencia de lo cual recibieron numerosas mercedes. El linaje incorporó entonces a su señorío diversas villas alavesas como Peñacerrada (1377), Salinillas de Buradón, Labastida (1370) y Salinas de Añana (1391).

5 Ambos ejercieron como repostero mayor del rey, y el último fue además alcalde mayor de la provincia de Guipúzcoa. AGS. Patronato Real, $\mathrm{n}^{\circ}$ 5044, (Privilegio de Enrique IV firmado en Segovia el 13 de diciembre de 1464).

6 AHN. Consejos. Leg. 11.552. Exp. 887, sin foliar; Esta costumbre fue derogada por el administrador Matías de Valparda en 1742, lo que ocasionó las protestas de los salineros a través de un memorial enviado a la Corte en 1744. AHN. Junta de Incorporaciones. Leg. 11.553. Exp. 942, ff. $1 \mathrm{r}-6 \mathrm{v}$.

7 Mantuvo el conde las alcabalas, los diez mil maravedíes de sueldo y cien reales para cien gallinas. No obstante, en 1579 medió pleito entre el concejo y vecinos de la villa y el conde, que se resolvió mediante una transacción convenida entre el conde Rodrigo Sarmiento y el concejo de Añana por la cual aquel renunciaba a tales ingresos.

8 A raíz del estanco se le señaló una compensación de 57.584 reales anuales, a pesar de que él afirmaba que le producían más de 80.000 reales y 300 fanegas de sal al año. Catorce años después del estanco se le debían aún 115.628 reales. Los tasadores comprobaron cómo algunos años el conde había ganado 10.000 ducados con sus salinas, y propusieron se le dieran de 6.500 (71.500 reales) a 7.000 ducados (77.000 reales) de renta anual. UlLOA, Modesto: ob. cit., pág. 392. 
completamente separadas y dispersas por todo el Valle Salado, mezcladas las de unos propietarios con otros y sin posibilidad de permuta, dado que todas ellas solieron formar parte de los bienes vinculados, ya de laicos, ya de eclesiásticos. Ello dificultó extraordinariamente la realización de obras de cierta envergadura durante toda la Edad Moderna, y así el Valle fue creciendo con cierto desorden, pasando de unas 2.500 eras a finales del siglo XVI a superar las 4.500 en el momento en que se aprobó la ley del Desestanco de 1869. Pero lo importante es que, además de sus eras, los herederos asociados en la Comunidad conservaron la capacidad de seguir explotando las mueras, aunque éstas se reconocieran como un ius regalia.

\section{EL DIEZMO-SEÑOR Y LOS DERECHOS SOBRE LAS MUERAS}

Y es aquí donde entra en juego el objeto del presente estudio, ya que para poder hacerlo se obligaron a pagar al rey el llamado diezmo-señor, un canon cuyo origen desconocemos pero que, en cualquier caso, los herederos de las salinas abonaron puntualmente desde 1564 hasta el año 1906. A pesar de su nombre, no era propiamente un diezmo, sino el exponente de una suerte de contrato enfitéutico establecido entre la Corona y los herederos por el cual aquella conservó el dominio directo sobre las mueras y éstos el usufructo, el «aprovechamiento exclusivo y el dominio útil de las mismas»?. En otras palabras, gracias a él los salineros se garantizaron durante siglos su capacidad para fabricar sal, en la medida en que les permitía hacer uso del mineral salino reconocido como propiedad de la Corona. Esto explica que desde entonces y hasta el siglo XX, el mantenimiento de ese canon fuese una cuestión prioritaria para la Comunidad de Herederos, en particular siempre que se introdujeron cambios en la administración de las salinas o de sus rentas.

El diezmo-señor fue abonado siempre en especie y, a juzgar por su nombre, puede presumirse que en el tiempo en que se estableció el contrato tal vez pudo representar el $10 \%$ de la cosecha anual. Pero en el transcurrir de los siglos la Corona percibió por ese concepto una cantidad fija de 3.610 fanegas anuales en la medida de Ávila ${ }^{10}$, que comenzó a descender a raíz de la desamortización

\footnotetext{
9 La enfiteusis se define como una cesión perpetua o por largo tiempo del dominio útil de un inmueble mediante el pago anual de un canon al que hace la cesión, el cual conserva el dominio directo. Como reconocía Adrián Herrán, uno de los miembros de la Comunidad de Herederos de Añana en el siglo XIX, el diezmo-señor se le venía pagando al rey desde tiempo inmemorial «como reconocimiento del dominio eminente y directo sobre todos los minerales» y aseguraba a los Herederos el derecho a explotar las mueras. HERRAN, Adrián.: Memoria de las fábricas de las salinas de Añana reformada después de la ley de 16 de junio de 1689 sobre desestanco de la sal, Vitoria, 1883, págs. 24-25.

10 Un informe elaborado en 1582 por el administrador de las salinas del partido de Castilla la Vieja, Benito Díez, contabilizaba el valor del diezmo-señor en la medida de diez celemines en la cual el montante del gravamen ascendía a 4.333 fanegas anuales. El citado administrador hace la
} 
hasta ser sustituida a partir de 1883 por una cantidad en metálico. No obstante, además de lo aportado a la Corona, el diezmo-señor tenía otro componente cuyo origen y naturaleza hoy por hoy también desconocemos, aunque tal vez fuera en él donde el término diezmo adquiría su significado más textual: los tercejones. En efecto, según un informe realizado en 1582 por el administrador de las salinas del partido de Castilla la Vieja Benito Díez, se conocían con este nombre un conjunto de cargas que los herederos abonaban a diversas entidades eclesiásticas vinculadas con la villa, a saber: 416 fanegas y 8 celemines al cabildo eclesiástico de la villa, más otras tantas al arcediano de Valpuesta ${ }^{11}$ —que participaba también de otros diezmos- más otras 138 fanegas y 4 celemines a las iglesias de San Cristóbal y Santa María de Villacones ${ }^{12}$; cargas estas últimas conocidas precisamente así, como tercejones y que, como señalaban los herederos en el siglo XIX, se adjudicaban a la plana de la Comunidad ${ }^{13}$. Ahora bien, por importante que fuera el diezmo-señor no fue ni mucho menos la única carga que aquellos tuvieron que abonar para poder elaborar su sal. Normalmente se recaudaba junto con el situado — 1.391 fanegas anuales_- con el que se hallaban gravadas algunas granjas que en algún tiempo habían pertenecido a monasterios, tal vez restos de algunos juros situados sobre las rentas de las salinas $^{14}$. En total 5.973 fanegas anuales, lo que repesentaba algo más del $17 \%$ de la cosecha ${ }^{15}$.

conversión del montante a la medida de Ávila y será en ésta en la que el diezmo-señor aparezca consignado en adelante. ATHA. Fondos Especiales. Salineros. Caja 2. Carp. 13, f. 7 r.

${ }_{11}$ Hasta finales del siglo XI Valpuesta fue uno de los tres obispados que, junto con el de Álava y el de Pamplona, agrupaba al territorio vasco. En aquella fecha, se produjo una reorganización de las diócesis episcopales: las de Álava y Valpuesta fueron absorbidas en las de Calahorra y Burgos respectivamente. Así, quedaron incorporadas en el obispado de Burgos numerosas localidades alavesas, entre ellas la de Salinas de Añana. El arcediano era el superior de los ministros de la iglesia primitiva y se encargaba de los asuntos temporales junto con los obispos. CATALÁn MARTINEZ, Elena: El precio del Purgatorio. Los ingresos del clero vasco en la Edad Moderna. Bilbao, 2000, pág. 28 y ss.

12 ATHA. Fondos Especiales. Salineros. Caja 2. Carp. 13, f. 7 r.

13 ATHA. Fondos Especiales. Salineros. Caja 19. Carp. 49, sin foliar.

14 La falta de una tesorería única que asegurase una garantía global por parte de la Corona en el pago de los asientos, determinó que éste fuese asegurado comprometiendo a ese objetivo rentas determinadas como las alcabalas, el almojarifazgo, juros de caución, luego llamados de resguardo, que en caso de necesidad daban origen a la figura del situado, que no siempre procede de los asientos y que consiste en el derecho prioritario de un particular a realizar ciertas cantidades de dinero tomándolas directamente de una determinada renta y de un lugar concreto. ARTOLA, Miguel: La Hacienda del Antiguo Régimen. Madrid, 1982, pág. 68.

15 Algo así como el 17,56 \% de la cosecha, que a finales de aquella centuria se cifraba en una media de 34.000 fanegas Son datos para el periodo 1594-1607. PORRES MARIJUÁn, Rosario: Sazón de manjares y desazón de contribuyentes. La sal en la Corona de Castilla en tiempos de los Austrias, Bilbao, 2003, pág. 97. 
Como se explicará más adelante, el pago del diezmo-señor comenzó repartiéndose equitativamente entre todos los propietarios de las eras en función de las que cada uno tuviese, aunque luego pasó a convertirse en "cantidad fija sobre cada una de las granjas - que era la unidad de explotación compuesta por todas las eras de un mismo propietario- sin que después haya sufrido alteración alguna» transmitiéndose como carga real afecta a las mismas eras, que aparecía consignada en sus títulos de propiedad como se consignaba en ellos qué derechos sobre las mueras correspondían a cada era según el reparto establecido en el llamado Libro Maestro o Libro de Repartimiento ${ }^{16}$. Dicho de otro modo, los derechos particulares a las mueras obtenidos mediante la contribución al diezmo-señor, pasaron a consignarse en los correspondientes "títulos de pertenencia» o de propiedad de las eras, sin que la Corona tuviese otros derechos sobre las mismas mueras que los que le estaban asignados como un heredero más sobre aquellas eras de su propiedad, que o bien se reservó o fue adquiriendo con el tiempo, y que eran gravadas con el canon como las demás ${ }^{17}$.

En efecto, tras el estanco de 1564 la Corona se reservó sus propias eras de producción, a las que con el transcurrir de los siglos fue añadiendo otras por compra o enajenación. Según una tradición que permaneció vigente durante toda la Edad Moderna, para alimentarlas se reservaba para sí el aprovechamiento de ciertas mueras durante tres días a la semana — los días del Reyentre las cuatro de la mañana y las tres de la tarde, si bien parece que las cedía a otras entidades - en particular conventos - cuando no disponía de eras propias o las daba en arriendo. El resto de los herederos tenían igualmente consignados sus días y horas de aprovechamiento de las mueras en el Libro de Repartimiento, con títulos muy antiguos de pertenencia adscritos, como se ha dicho, a los de propiedad de las mismas eras.

16 ATHA. Fondos Especiales. Salineros. Caja 7. Carp. 46, ff. 16v-17r. El Libro Maestro era determinante para mantener un orden exacto en la distribución de la salmuera. El que rigió durante toda la Edad Moderna se elaboró en el siglo XVI y aunque se le fueron añadiendo algunos cambios según iba creciendo el Valle, lo cierto es que, como reconocían los herederos, el reparto de las mueras había llegado a regirse más «por tradición y práctica que se sucede entre los salineros que por lo que pueda deducirse de la lectura y explicación de su texto». Sólo en 1860, cuando la fisonomía del Valle había cambiado notablemente y cuando incluso el sistema de fabricación de la sal era distinto, los Herederos se decidieron a hacer otro libro, más ajustado a la realidad de las granjas y los derechos de disfrute de las mueras.

17 ATHA. Fondos Especiales. Salineros. Caja 7. Carp. 46, f. 18v. El número de herederos propietarios de las salinas se mantuvo inamovible durante toda la época moderna en 36 individuos, de modo que el incremento del número de eras se hizo siempre entre ellos, lo cual explicaría que el diezmo-señor se adjudicase a la «granja» que era la unidad de explotación. 


\section{TABla 1: CARGAS SOBRE lOS HEREDEROS DE LAS SALINAS DE AÑANA (en fanegas) SIGLOS XVI-XIX}

\begin{tabular}{|c|c|c|c|c|c|}
\hline \multirow[t]{2}{*}{ ETAPA } & \multicolumn{2}{|c|}{ DIEZMO-SEÑOR } & \multirow[t]{2}{*}{$\begin{array}{c}\text { TOTAL } \\
\text { DIEZMO }\end{array}$} & \multirow[t]{2}{*}{ SITUADO } & \multirow[t]{2}{*}{ TOTAL } \\
\hline & CORONA & TERCEJONES & & & \\
\hline Siglo XVI & 3.610 & 972 & 4.582 & 1.391 & 5.973 \\
\hline $\begin{array}{l}\text { Siglo XVIII hasta } \\
1846\end{array}$ & 3.610 & 519 & 4.129 & 1.391 & 5.520 \\
\hline $1846-1870$ & 2.618 & 519 & 3.137 & 547 & 3.684 \\
\hline $1870-1883$ & 2.579 & - & 2.579 & 547 & 3.126 \\
\hline $1883-1906$ & 2.289 & - & 2.289 & 547 & 2.836 \\
\hline
\end{tabular}

Como se puede ver por la tabla 1 , con el tiempo — tal vez desde la introducción del sistema del cupo en 1598 aunque sólo lo he podido constatar desde el siglo XVIII-, el peso de estas cargas se fue desacelerando. En principio a causa de la rebaja de 453 fanegas anuales en el valor de los tercejones y de ciertos cambios introducidos en su distribución ${ }^{18}$. El cabildo de los beneficiados de Añana y el arcediano de Valpuesta fueron los grandes perdedores con el cambio, y en menor medida las iglesias de la villa ${ }^{19}$. Aquel perdió 300 fanegas y 3 celemines, las parroquias apenas cuatro celemines y el arcediano nada menos que 394 fanegas con 8 celemines. En total, 695 fanegas y media, casi la mitad de las cuales fueron a parar a la Villa de Añana y más adelante a la Comunidad de Herederos (tabla 2). No por ello vieron esas comunidades descender sus ingresos, o no al menos en la cantidad que esas cifras indican. $Y$ es que, en cierto modo, la Comunidad establecerá compensaciones para aquellas entidades a la hora de distribuir el beneficio del cupo anual que entró en vigor a partir 1598. Reducido pues a 519 fanegas, hasta el desestanco de 1869 el valor de los tercejones se mantuvo inamovible, aunque según parece desaparecieron en 1870 . Sumadas aquellas a las 3.610 fanegas que en concepto de diezmo cobraba la Corona, el montante global del mismo se mantuvo en 4.129 fanegas anuales hasta la desamortización del siglo XIX.

18 Un documento del año 1647 señala que los herederos pagaban al año 4.300 fanegas en concepto de diezmo y 1.900 de situado, lo cual dispararía a 6.200 el montante global de ambos. Sin embargo, en mi opinión, el dato debe ser tomado con cierta cautela en la medida en que el documento tenía como objetivo obtener del rey un incremento del precio de fábrica para los Herederos, que adoptan el habitual tono victimista cargando las tintas sobre el peso de los gravámenes. ATHA. Fondos Especiales. Salineros. Caja 1. Carp. 10, ff. 1r-1v.

19 Tal vez por ello, en el reparto del cupo anual establecido desde 1598 y del que más adelante se hablará, el cabildo será compensado con el valor de 300 fanegas, el arcediano con el de 78 y la iglesia de Villacones con el de 21 fanegas. 
TABLA 2: EVOLUCIÓN EN EL REPARTO DE LOS TERCEJONES (fanegas/año)

\begin{tabular}{|lccccc|c}
\hline FECHA & $\begin{array}{c}\text { CABILDO } \\
\text { BENEFICIADOS }\end{array}$ & $\begin{array}{c}\text { IGLESIAS } \\
\text { AÑANA }\end{array}$ & $\begin{array}{c}\text { ARCEDIANO } \\
\text { VALPUESTA }\end{array}$ & $\begin{array}{c}\text { VILLA } \\
\text { ANANA }\end{array}$ & TOTAL \\
\hline SIGLO XVI & $\begin{array}{c}416,8 \\
(42,88 \% \\
\text { del total })\end{array}$ & $\begin{array}{c}138,4 \\
(14,23 \%)\end{array}$ & $\begin{array}{c}416,8 \\
(42,88 \%)\end{array}$ & - & 972 \\
\hline $\begin{array}{l}\text { SIGLO XVIII } \\
\text { hasta } 1869\end{array}$ & $\begin{array}{c}116,5 \\
(22,4 \%)\end{array}$ & $\begin{array}{c}138 \\
(26,5 \%)\end{array}$ & $\begin{array}{c}22 \\
(5,3 \%)\end{array}$ & $\begin{array}{c}242,5 \\
(46,7 \%)^{*}\end{array}$ & 519 \\
\hline
\end{tabular}

* Con el tiempo a la Comunidad de Herederos.

Entonces, las cargas sobre los salineros volvieron a descender, aunque esta vez a causa del diezmo-señor y el situado. El proceso desamortizador afectó en principio a las eras del clero, pero como después acabaron siendo vendidas sin aquellos recargos, acabó repercutiendo en su cómputo global y afectando a todos los propietarios de las eras, incluidos los laicos. El diezmo-señor quedó reducido a 3.137 fanegas, de las cuales la Corona se llevaba 2.618 mientras los tercejones permanecían en 519. El situado descendió a 547, con lo que el montante global de las cargas sobre los herederos se situó en 3.684 fanegas anuales. A éstas se añadieron otras rebajas. Sin que se pueda precisar cuando, pero en todo caso siempre entre 1863 y 1870 , se redujo de nuevo a causa de la venta sin recargo de las llamadas «eras del Vadillo» —es decir las del convento de Santa María del Vadillo en Burgos- gravadas hasta entonces con 39 fanegas en concepto de diezmo y situado. En 1870 desaparecieron las 519 fanegas de los tercejones $\mathrm{y}$, trece años después se produjo una nueva reducción al haber enajenado la Corona ciertas eras pertenecientes al Hospital del Rey de Burgos gravadas con 289 fanegas y 8 celemines $^{20}$. Así, en 1883 las cargas que los herederos debían soportar quedaron reducidas apenas a 2.836 fanegas, que en esa misma fecha pasaron a abonarse en pesetas (tablas 3 y 4 ).

\section{TABLA 3: EVOLUCIÓN DEL NÚMERO DE FANEGAS PERCIBIDAS POR LA CORONA EN CONCEPTO DE DIEZMO-SEÑOR Y SITUADOS, SIGLOS XVI-XX}

\begin{tabular}{|cc|}
\hline ETAPA & FANEGAS \\
\hline $1564-1846$ & 5.001 \\
\hline $1846-1863$ & 3.165 \\
\hline i-? -1883 & 3.126 \\
\hline $1883-1906$ & $2.836^{*}$ \\
\hline * Aunque calculado primeramente en fanegas, en el mismo año de 1883 pasó a abonarse en di- \\
\begin{tabular}{l} 
nero en la misma cantidad, es decir, 2.836 pesetas. \\
\hline
\end{tabular} \\
\hline
\end{tabular}

20 ATHA. Fondos Especiales. Salineros. Caja 7. Carp. 10, ff. 25r-26r. 


\section{TABLA 4: VALOR EN REALES DE LO PERCIBIDO POR LA CORONA EN CON- CEPTO DE DIEZMO-SEÑOR Y SITUADOS ${ }^{21}$}

\begin{tabular}{|c|c|c|}
\hline 1564-COMIENZOS XVII & HASTA 1632 & $1632-1801$ \\
\hline 30.006 & 40.008 & 55.121 \\
\hline
\end{tabular}

\section{EL DIEZMO-SEÑOR Y LA ORGANIZACIÓN DEL ENTRAMADO SALINERO}

Pero al margen de su cuantía, durante toda la Edad Moderna el valor del diezmo-señor radicó en que fue el índice de referencia en torno al cual se organizaron en Añana la venta de la sal y la distribución de sus beneficios entre la Corona y la Comunidad de los Herederos. En otras palabras, desde que en 1564 las salinas se convirtieron en fábrica real, el diezmo-señor pasó a ser el baremo para determinar en qué cantidad y en qué orden aquella iría tomando la cosecha a los distintos propietarios. Según el informe de Benito Díez ya citado, toda la distribución y venta de la sal giraba en torno a él ${ }^{22}$. Para recaudarlo de una forma equitativa, todos los años se hacía un repartimiento entre los propietarios de las eras, de forma que quien tenía más pagaba más. Y, a mayor contribución en el diezmo, mayor cantidad de cosecha a entregar en los almacenes reales. La sal que así obtenía la Corona, junto a la que se producía en sus propias eras, pasó a ser conocida como la sal de todo fecho o sal propia de su magestad, que se vendía toda fiada y con plena ganancia para la Real Hacienda — seis reales en el siglo XVI, ocho en la primera parte del siglo XVII y once desde 1632 en adelante - siendo administrada por el receptor, un oficial de nombramiento real «el cual la guia con los vecinos en quien se reparte la dicha sal de diezmo-señor y situado para cobrar de ellos lo que se debe a su magestad» ${ }^{23}$.

De esa forma se distinguía de la otra sal, la sal de herederos en la que, vendida al mismo precio pero siempre al contado, la Corona obtenía un beneficio neto de cinco reales tras descontar el precio de fábrica que por aquel entonces entregaba a los herederos, y que ascendió a 1 real por fanega hasta el año 1609. De ese real, el beneficio neto para el heredero no llegaba ni siquiera a la mitad, pues se debían descontar el salario «al granjero de la manifatura», el diezmo que pagaba al rey, la merma (que solía ser de un $10 \%$ ) y un maravedí

21 El cálculo se ha efectuado de acuerdo a la evolución del precio tasado en cada etapa, 6, 8 y 11 reales.

22 ATHA. Fondos Especiales. Salineros. Caja 2. Carp. 13, (Salinas de Añana, 3/IV/1582). «Informe sobre el adra de la guía de la sal que pertenence a su magestad que debe dar al receptor de las salinas de Añana» elaborado por Benito Díez, administrador de las salinas de Castilla la Vieja, asistiendo como testigos Diego Díez Arebalillo, Mateo de Montoya y Juan de Portillo.

23 Si algún año se vendía más sal de todo fecho de la que al rey le pertenecía, el receptor la guiaba entre los vecinos, por haberse acabado la del rey, lo que solía dar lugar a quejas porque se sospechaba que el funcionario primaba a sus amigos. 
de la entrada en los almacenes reales de la villa. Eso sin contar los gastos en el mantenimiento de la infraestructura, que en el caso de Añana, y a diferencia de otras salinas, dependía de los propietarios ${ }^{24}$. Pues bien, como se producían más fanegas de las que se llegaban a vender, para que esas ventas se distribuyesen con equidad entre los salineros había «çierta orden antigua» que en Añana se llamaba adra o tanda. Y para ordenar y controlar el adra también se utilizaba como referente el diezmo-señor. Como se ha dicho, para recaudar éste se hacía un repartimiento entre los poseedores de eras. Cuando llegaba la época de vender la sal de herederos, y a fin de que ningún vecino se viera agraviado, se le daba a cada uno tantas fanegas de tanda o adra como tenía de carga en el repartimiento del diezmo-señor y el $10 \%$ más. De esta suerte, por ejemplo, a quien pagaba 100 fanegas de repartimiento, se le otorgaban 110 de adra. Así, la venta iba de vecino en vecino, repartiendo a cada uno lo suyo hasta que, terminada la ronda entera en la villa, la rueda volvía a comenzar.

Para llevar a cabo con riguroso orden el adra el concejo de la villa nombraba un «encargado de guiar» o adrero, que actuaba bajo juramento tomado por las propias autoridades municipales en el que, entre otras cosas, se comprometía a no dar a nadie más adra de la que le correspondiera. El adrero llevaba un doble registro en dos grandes libros encuadernados. En uno anotaba las fanegas que cada vecino de la villa con eras para hacer sal, así como los monasterios e iglesias que igualmente las poseían, debían en concepto del diezmo-señor; en el otro registraba lo que a cada uno de esos vecinos, iglesias y monasterios se les había de vender en cada tanda o «adra que les biene y la forma y manera que se les da». Como se verá más adelante, pronto surgirían recelos entre ambos operarios, el receptor de nombramiento real y el adrero de nombramiento municipal, entre otras cosas porque éste no podía llevar cuenta del registro de aquel. En los años 80 cambiarían las cosas.

Y es que la ley de 1564 había traido consigo un cierto desconcierto. Por lo que sabemos, durante los tres primeros años que siguieron al estanco (15641566) la Hacienda Real no cobró el diezmo-señor, pero bastantes años después, nada menos que en 1575, reclamó a los salineros las 13.000 fanegas corres-

24 Un informe elaborado en 1616 por el corregidor de Miranda de Ebro, el licenciado Bracamonte, proporciona algunos datos al respecto. Según ese documento, cuando la Corona pasó a pagar 42 maravedíes por cada fanega al Heredero, éste tenía de costa la mitad, es decir, 21 maravedíes en cada fanega, pues debía pagar 8 maravedíes al «granjero de la manifatura», 7 al rey en concepto de diezmo, 5 maravedíes más que se calculaban por la merma y 1 maravedí más que debía abonar al entrojar la sal en los almacenes reales. Esto significa que le quedaban libres otros 21 maravedíes y en ocasiones ni siquiera eso porque los Herederos de Añana, a diferencia de los de las otras salinas, debían asumir los gastos de mantenimiento de las infraestructura y la limpieza de los pozos y recogederos del agua salada. Mientras, según ese mismo informe, en Poza, de los 60 maravedíes apenas debían descontar 3 por el diezmo, y les «quedan buenos» los otros 57. Finalmente en Rosío, de los 38 maravedíes por fanega apenas debían descontar el diezmo y la merma «y no otra cosa alguna porque toda la costa que hacen la paga su magestad». ATHA. Fondos Especiales. Salineros Caja 8. Carp. 23, ff. 2v-3r. PORReS MARIJUAN, Rosario: Sazón de manjares... pág. 80. 
pondientes a aquel periodo, que en su día no habían sido abonadas a causa de las inclemencias del tiempo pero también por la inoperancia de los administradores, que ni cobraron las fanegas del diezmo ni las vendieron cuando los vecinos disponían de ellas, "y se les mato en los terrazos con llubias y niebes abenydas». A los productores no les quedaba sino demandar clemencia del rey, que se les perdonase la deuda en parte o en su totalidad o, en todo caso, que se les diesen unos plazos asequibles para poder redimirla sin agobios y sin las presiones del administrador. Algunos vecinos debían cantidades muy altas y «si lo obiesen de pagar en un plaço quedarian perdidos y se yrian del pueblo» ${ }^{25}$. No obstante, hasta el siglo XIX esta excusa fue recurrente siempre que la Comunidad padeció problemas financieros o de otra índole, para los que no parecía encontrar otra salida que la condonación del diezmo-señor.

Una vez finalizado el primer estadio de arrendamiento particular, entre los años 1573 y 1582 se pasó a un régimen de administración directa por la Real Hacienda, durante el cual el partido de Castilla la Vieja estuvo en manos del administrador Gonzalo de Portillo. Pues bien, esta fase se mostró al parecer propicia para arreglar cuentas con la Corona y ajustar todo aquello que tras el estanco no había sido perfilado convenientemente. Entre esas cuestiones, los herederos de Añana demandaron de la administración una mayor agilidad en lo relativo a la gestión del diezmo-señor ${ }^{26}$. Se quejaron entonces del perjuicio que les causaba el que se dilatara su cobro, exigiendo que se les tomase en el momento de hacer raxa sal como siempre habían tenido por costumbre, porque al dilatarlo «se le deshace y hurtan y no tienen con que pagar».

Pero no era ésta la única cuestión que les preocupaba en relación con este tema. Como ya se ha señalado con anterioridad, diezmo y situado eran fundamentales en la regulación de los derechos de venta de la sal entre los propietarios. $\mathrm{Y}$ aunque ninguno de los que fueron consultados - entre otros el adrero municipal- admitió haberlo visto personalmente, todos confesaron haber oído rumores sobre los abusos que el receptor y otros oficiales reales cometían a la hora de regular la venta de la sal de todo fecho, perjudicando la de la sal de herederos. Esos rumores que tan insistentemente se habían extendido en la villa, venían a decir que el receptor real «so color de guiar la sal que se debe a su magestad bende otra sal suia propia e de sus amigos». En otras palabras, se sospechaba que al guiar la sal del rey sin que el adrero municipal pudiese tomar cuenta, los oficiales reales cometían irregularidades, desatendiendo el principio de igualdad y agraviando a los herederos, que veían cómo su sal se quedaba sin vender ${ }^{27}$. Por ello se atrevieron a demandar en la Corte que nadie que estuviese ocupado como contador y en la hacienda de las salinas pudiese arren-

25 Porres MARIJuÁn, Rosario: «La política fiscal de Felipe II en Álava: el estanco de la sal de 1564», en Reguera, Iñaki y PORReS MARIUján, Rosario: Poder, pensamiento y cultura en el Antiguo Régimen, San Sebastián, 2002, pág. 63.

26 ATHA. Fondos Especiales. Salineros. Caja.8. Carp. 21 (Salinas de Añana.14/II/1575).

27 ATHA. Fondos Especiales. Salineros. Caja 2. Carp. 13, f. 6r. 
dar eras de sal, ni de monasterios ni de particulares, porque «con el favor que tienen, venden y gastan toda su sal con brebedad y los demas resciben mucho daño por que no benden la suya por tenerlas de otra manera si no fueren suyas propias». Como se atreverían a exigir después que no se admitiese a los oficios de «la fábrica» a quien estuviese empleado en la administración de las rentas, ni a los escribanos públicos ${ }^{28}$.

En realidad, lo que pretendían los herederos era obtener para sí y para la villa un mayor control sobre la distribución de la sal de todo fecho a través del adrero. Bastaba con que éste pudiese tener notificación puntual del registro que a su vez llevaba el receptor real. Y eso fue ni más ni menos lo que pidieron al administrador de las salinas y más tarde al Consejo de Hacienda: que el adrero pudiera tener relación de lo que el receptor anotaba en su libro, de forma que las «albalas» que éste guiase de la sal de todo fecho no pudieran medirse sin que previamente aquel hubiese tomado nota. Se pensaba que con este sistema se disiparían las sospechas sobre los oficiales reales, y se ajustaría el sistema de igualdad que en el adra solía regir, evitando toda posibilidad de agravio a los vecinos. Este párrafo que reproducimos indica hasta qué punto la desconfianza hacia los oficiales reales se trocaba en absoluta credibilidad para con los locales:

«no habrá fraude ni puede haberlo — decían— porque el adrero en acabando de enchir a cada vecino lo que debiere no asentara mas por aquella quenta y aunque baya guiada del dicho receptor no la querra asentar asta que le guie con otro que deva sal (...) e despues que desta manera se ubiere acabado de guiar toda la sal que se deviere a su magestad el tiempo que sobrare y la sal que se bendiere de todo fecho sera por su adra como ba lo demas de los herederos y questo es en ygualdad» 29 .

Lo cierto es que a raíz de estas denuncias el administrador de las salinas de Castilla la Vieja, Benito Díez, se presentó en Añana para intentar clarificar los hechos por orden del Consejo. Corría el tercer día del mes de abril de 1582. Tras haber consultado con varios vecinos y pasado revista a los libros del adrero, optó por dar la razón a los herederos y, mientras el Consejo de Hacienda tomaba cartas en el asunto, el administrador aceptó que el adrero municipal llevase buena cuenta de la sal de todo fecho guiada por el receptor «de manera que a ningun vecino se le de mas sal de todo fecho de aquella que debiese al rey». Eso sí, se aseguraba de que la operación no daría lugar a demoras ni significaría coste adicional alguno ${ }^{30}$.

28 Esta cuestión sería regulada finalmente por una real orden de 4 de noviembre de 1786. AHN. Escribanía de Cámara de Escariche. Leg. 24.260. Exp. 25 (Año 1789) y Escribanía de Cámara de Granados. Leg. 27.304. Exp. 10.

29 ATHA. Fondos Especiales. Salineros. Caja 2. Carp. 13, f. 3v.

30 Ibídem, ff. 6v-7r. 


\section{EL DIEZMO-SEÑOR Y EL RÉGIMEN DEL CUPO}

Pero la función del diezmo-señor no quedaría ahí. En 1598, y tras largos años de disputas entre Añana y Poza por controlar los mercados del partido de Castilla la Vieja, ambas decidieron firmar una concordia con la mediación de la Corona que, aunque fijada por dieciocho años, acabó por mantenerse en vigor nada menos que hasta 1801. En ella, la Hacienda Regia se comprometió a pagar anualmente a los salineros de Añana la fábrica de un cupo de 30.000 fanegas de sal — de herederos - que les pagaría puntualmente tanto si se vendían como si no, y a recogerles el resto de la cosecha, las (de)masías que, por el contrario, sólo les abonaría en el momento en que se vendiesen. Ciertamente, trabajar para la Hacienda Real representaba algunas ventajas. Que la Corona fuese el cliente por excelencia o el único era a priori garantía de una demanda segura y regular. Pero también planteaba inconvenientes. El primero, que sería ella la que marcaría el precio de fábrica, y no siempre el más conveniente para los productores. El segundo, que la Hacienda resultaba mal pagadora, y los retrasos e impagos solían ser más habituales de lo deseable. Las reales fábricas de la sal de Añana no fueron ninguna excepción en eso. De hecho, los atrasos en el pago de las masías se hicieron endémicos desde aquel mismo momento ${ }^{31}$ y el precio de fábrica fue subiendo con cuentagotas. Los 34 maravedíes (1 real) por fanega que desde 1564 aún seguían pagándose en 1598, se transformaron en 42 a partir de 1609, 54 en 1632 y 68 en 1647, precio éste último que permaneció en vigor hasta la nueva contrata de 1801.

Pues bien, desde que el sistema de cupo se puso en marcha, el diezmo-señor se empleó como referente para distribuirlo entre los herederos. Un documento de la segunda mitad del siglo XVIII nos da cuenta puntual sobre cómo se llevaba a cabo la distribución, al tiempo que nos aporta las primeras noticias sobre la identidad de los herederos propietarios de las salinas, más allá de los escasos datos que sobre los monasterios nos venía ofreciendo la documentación medieval. A dos reales la fanega (68 mrs), el valor del cupo ascendía anualmente a 60.000 reales que la Corona o sus arrendadores abonaban a los salineros. De ellos, 58.962 se pagaban a los herederos y los 1.038 restantes, que procedían de las 519 fanegas de los tercejones y que se pagaban a dos reales como el resto del cupo, se abonaban a las instituciones correspondientes. Pues bien, a estas alturas del setecientos, para repartir el valor del cupo entre los propietarios se aplicaba y pagaba a cada heredero una ratio de 13 reales por cada fanega de diezmo-señor ${ }^{32}$. Y así era en todos los casos salvo en tres, el cabildo de los beneficiados, el arcediano de Valpuesta y la iglesia de Santa María de Villacones, a los cuales además del reparto correspondiente a su respectivo diezmo-

31 Porres Marijuan, Rosario, Sazón de manjares.., págs. 104-106.

32 Para establecer el diezmo-señor que correspondía pagar a cada heredero, se aplicaba una ratio de 7,5 fanegas repartidas sueldo a libra se supone que por cada era. 
señor, se les añadían otras cantidades seguramente como compensación al descenso de los tercejones al que antes se aludía. Así, al cabildo se le añadía el valor de 300 fanegas de sal (por los doce Beneficiados, a razón de 25 fanegas cada uno); al arcediano se le sumaba el valor de 78 fanegas por llevador; y el valor de otras 21 fanegas se entregaban a la iglesia de Santa María de Villacones (en la tabla 5 aparecen señaladas con *). En total, 399 fanegas que, al mismo precio de los 13 reales por fanega, se contabilizaban en la parte del cupo correspondiente a los herederos hasta completar los 58.962 reales pertinentes ${ }^{33}$.

TABla 5: Distribucion de los 60.000 REALES Del CUPO ANUAL (SEGUNDA MITAD DEL SIGLO XVIII)

HEREDEROS TERCEJONES
$58.962+1.038 \stackrel{\text { TE }}{=} \quad 60.000$

\section{REPARTO DEL VALOR DE LOS TERCEJONES}

\begin{tabular}{|c|c|c|}
\hline INSTITUCION & VALOR EN REALES & $\begin{array}{c}\% \text { SOBRE } \\
\text { TERCEJONES }\end{array}$ \\
\hline Villa de Añana & 485 & $46,72 \%$ \\
\hline Cabildo Eclesiástico de Añana & 233 & $22,44 \%$ \\
\hline Iglesia de San Cristóbal de Añana & 138 & $13,29 \%$ \\
\hline Iglesia de Santa María de Villacones de Añana & 138 & $13,29 \%$ \\
\hline Arcediano de Valpuesta & 44 & $4,23 \%$ \\
\hline TOTAL & 1.038 & $99,97 \%$ \\
\hline
\end{tabular}

\section{REPARTO DEL VALOR DEL CUPO ENTRE LOS HEREDEROS}

\begin{tabular}{|lcc|}
\hline HEREDERo & $\begin{array}{c}\text { DIEZMO-SEÑoR } \\
\text { (fanegas) }\end{array}$ & $\begin{array}{c}\text { VALOR } \\
\text { (reales) }\end{array}$ \\
\hline Villa de Añana & 17,5 & 228 \\
\hline Cabildo Eclesiástico Añana & 126,5 & $5.551^{*}$ \\
\hline Curato de San Cristóbal de Añana & 3 & 39 \\
\hline Arcediano de Valpuesta & - & $1.015 *$ \\
\hline
\end{tabular}

33 Las compensaciones sumaban 399 fanegas que sumadas a los 4.129 del cómputo global del diezmo-señor contabilizaban un total de 4.528 fanegas. Sin embargo, en el documento que se ha utilizado se contabilizan $4.535,5$ que a 13 reales por fanega completa los 58.962 reales. La diferencia entre ambas cantidades es apenas de 7,5 fanegas, es decir, lo correspondiente a una era según la ratio establecida para aplicar el diezmo-señor, tal y como se señala en la nota anterior. 


\begin{tabular}{|c|c|c|}
\hline HEREDERO & $\begin{array}{c}\text { DIEZMO-SEÑOR } \\
\text { (fanegas) }\end{array}$ & $\begin{array}{c}\text { VALOR } \\
\text { (reales) }\end{array}$ \\
\hline Convento San Juan de Acre de Añana & 120 & 1.562 \\
\hline Iglesia de San Cristóbal de Añana & 104,5 & 1.370 \\
\hline Iglesia de Santa María de Villacones de Añana & 8 & $386 *$ \\
\hline Capellanía de Mata & 105 & 1.367 \\
\hline Capellanía de Contreras & 112,5 & 1.464 \\
\hline Capellanía de Calderón & 128 & 1.666 \\
\hline Cofradía de San Blas (las tiene el Cabildo) & 30 & 391 \\
\hline Hospital de Añana & 11 & 146 \\
\hline Juan Manuel de Corcuera & 193,5 & 2.521 \\
\hline Manuel de Fontecha (en manos de Lino Loma) & 22 & 286 \\
\hline Francisco de Loma (en manos de Lino Loma) & 59 & 768 \\
\hline Lino de Loma & 97 & 1.263 \\
\hline Agustín de Luyando & 185,5 & 2.414 \\
\hline Joseph Pisón y Romero & 107,5 & 1.399 \\
\hline Joseph de Tejada Eguiluz & 348,5 & 4.537 \\
\hline Michaela de Tejada & 58 & 755 \\
\hline Hermenegildo de Argüelles & 132,5 & 1.724 \\
\hline Vicente y Teresa Argüelles & 62,5 & 814 \\
\hline Enrique Marrón & 89,5 & 1.165 \\
\hline Emeterio Corcuera & 456 & 5.937 \\
\hline Joseph de Montoya & 186,5 & 2.427 \\
\hline Josepha de Corcuera & 64 & 833 \\
\hline Manuel de Luyando & 354,5 & 4.615 \\
\hline Vicente Zambrana & 178,5 & 2.324 \\
\hline Joseph Ramirez & 44 & 573 \\
\hline Joseph de Salazar & 49,5 & 645 \\
\hline Simón de Bustamante & 47 & 612 \\
\hline Formerio de Estrada & 55 & 717 \\
\hline Vínculo del Racionero Ochoa & 7,5 & 98 \\
\hline Plácido Humada (la iglesia de San Cristóbal) & 28 & 364 \\
\hline Manuel de Villegas & 36,5 & 475 \\
\hline Pedro Antonio Rubio & 34,5 & 449 \\
\hline Bernardo Olarte & 36,5 & 475 \\
\hline Francisca de Eguiluz (cabildo) & 30 & 390 \\
\hline Santiago Vidijo (Monasterio) & 10 & 131 \\
\hline Soto (en manos de Lino Loma) & 10 & 130 \\
\hline
\end{tabular}




\begin{tabular}{|c|c|c|}
\hline HEREDERO & $\begin{array}{l}\text { DIEZMO-SEÑOR } \\
\text { (fanegas) }\end{array}$ & $\begin{array}{l}\text { VALOR } \\
\text { (reales) }\end{array}$ \\
\hline Hospital del Rey de Burgos & 87,5 & 1.138 \\
\hline Covarrubias (Burgos) & 18 & 234 \\
\hline Santa María de Vadillo (Burgos) & 6 & 78 \\
\hline San Pedro de Cardeña (Burgos) & 36 & 468 \\
\hline Convento de Obarenes (Burgos) & 43,5 & 566 \\
\hline Monasterio de Valvanera (La Rioja) & 32,5 & 423 \\
\hline Santa María la Real de Vileña (Burgos) & 25 & 325 \\
\hline Nuestra Señora del Espino (Burgos) & 76 & 989 \\
\hline San Juan de Ortega (Burgos) & 24 & 312 \\
\hline San Miguel del Monte (Burgos) & 24 & 312 \\
\hline Monasterio de La Estrella (La Rioja) & 7 & 91 \\
\hline TOTAL & 4.129 & 58.962 \\
\hline
\end{tabular}

* Además de los reales correspondientes al diezmo-señor se añaden los correspondientes a la compensación.

La tabla número 5 nos permite calibrar varias cosas a un tiempo. En primer lugar, el extraordinario peso que la villa de Añana ha alcanzado en el cobro de los tercejones y el retroceso de las demás instituciones participantes en el reparto. Pero también, cómo el conjunto de la Comunidad de Herederos ha asumido en su parte del cupo la compensación de aquellas instituciones perdedoras, hasta un total de 5.187 reales ( 3.900 al cabildo, 1.014 al arcediano de Valpuesta y 273 a la iglesia de Villacones) que en el gráfico aparecen añadidos a los que a esas instituciones les correspondían por sus propias eras. Téngase en cuenta, que la iglesia de Santa María poseía eras apenas gravadas con 8 fanegas de diezmo, mientras que la de San Cristóbal poseía 104,5, lo que le reportaba por sí solo, y a trece reales por fanega, 1.370 reales al año. Además, por primera vez obtenemos datos sobre el verdadero reparto de la propiedad, siguiendo el principio de que cuanto mayor fuera ésta, mayor contribución en el diezmo-señor y mayor participación en el cupo anual. Los datos a este respecto son claros: Las instituciones religiosas se llevaban el 32,15\% del cupo (19.293 reales anuales), las instituciones laicas el $3,32 \%$ (1.997 reales) y los particulares el 64,51\% (38.710 reales).

Por otro lado, aunque el gran beneficiario del cupo parece ser el cabildo eclesiástico, no lo es tanto por su propio diezmo (126 fanegas y media) cuanto por la compensación referida. Sin embargo, si nos limitamos a los grandes contribuyentes en el diezmo-señor, y por tanto los grandes propietarios de eras en Añana, sin duda debemos hablar de particulares: don Emeterio Corcuera, con 456 fanegas de diezmo, don Manuel de Luyando, con 354,5 fanegas y don Joseph de Tejada Eguiluz que con 348,5 fanegas parecen ser los grandes pro- 
pietarios de eras en Añana por esas fechas y, de hecho, entre los tres se llevaban prácticamente el $25 \%$ del total del cupo. Los tres pertenecían a las más reputadas familias de la villa aunque no siempre eran oriundas de la misma. Los Luyando, por ejemplo, procedían de Orduña (Vizcaya), donde poseían su casa principal, si bien poseían casa-torre en la localidad alavesa de Espejo; los Hurtado de Corcuera procedían de Leciñana del Camino (Burgos). Los Tejada, en cambio, eran poseedores del mayorazgo que había fundado Francisco de Eguiluz apellido muy consolidado en Añana cuando menos desde el siglo XVI. Pero junto a ellos, en el cómputo del diezmo-señor sobresalían los Loma Osorio, oriundos de Sajazarra (La Rioja), que se asentaron en Añana a comienzos del siglo XVIII; o los Zambrana ${ }^{34}$, en este caso de raigambre establecida en la propia Salinas de Añana en el siglo XVI, parroquianos que eran de la iglesia de San Cristóbal y emparentados desde comienzos del siglo XVIII los Herrán, que en el siguiente se contarán entre los mayores propietarios de las eras; pero emparentados también con los Estrada procedentes de Santo Domingo de la Calzada, más tarde duques de Estrada, título que ostentarán los Zambrana; o los Argüelles y algunas más, que controlaron reiteradamente la Junta de la Comunidad de Herederos por el principio de que para ostentar los principales cargos de la misma era menester residir y tener casa abierta en la villa. Pero los había también foráneos, como los Bustamante, asentados en Logroño, o los Rubio de Briones, también en la Rioja, como riojano era al menos en origen el título del marqués de Ciriñuela que ostentaba don Joseph de Pisón, que vivía a caballo entre Añana y Santo Domingo de la Calzada.

Finalmente, quedaría por reseñar el peso de las otras instituciones religiosas en la propiedad de las eras de Añana y su participación en el cómputo global del diezmo-señor. A la cabeza, se hallan las instituciones eclesiásticas de la villa: en primer lugar, con 120 fanegas al año, el convento de San Juan de Acre de las religiosas comendadoras de la Órden de San Juan, que en los años setenta del siglo XVIII contaba con unas catorce monjas dedicadas, entre otros menesteres, a «formar jóvenes educandas en las labores propias de señoritas distinguidas» ${ }^{35}$; le seguían en importancia el cabildo eclesiástico con 126 fanegas y media, aunque su participación en el reparto del cupo anual fuera bastante mayor como ya se sabe; finalmente la iglesia de San Cristóbal $(104,5)$, que sería destruida años después en plena Guerra de la Independencia, muy lejos de la de la otra iglesia, la de Santa María de Villacones, que apenas tenía 8 eras de diezmo al año, lo cual explica que fuera compensada en el reparto del cupo anual. Es destacable el papel de las capellanías de Mata (105 fanegas), de Con-

34 Uno de ellos, José de Zambrana, ostentaba en el tramo final del siglo XVII y comienzos del XVIII el cargo de Secretario de su Majestad y del Gobernador y Virrey de los Estados de Milán aunque tenía señalada su vecindad en Añana. ARCHV. Pleitos Civiles. Escribanía Quevedo. Procesos Olvidados. C/11/1; Olim L.4. (Año 1700).

35 LANDAZURi y Romarate, José Joaquín: Obras históricas sobre la provincia de Álava, Vitoria, 1976. Tomo III, p. 219. 
treras $(112,5)$ y de Calderón (128), esta última fundada en el siglo XVII por el Nuncio de la Inquisición don Fernando Calderón en la parroquia de Santa María de Villacones de Añana y que fue pasando por las manos de sucesivos patronos, entre otros, Pedro Fernández de Arce, criado del rey y residente en Madrid; Antonio Fernández Sogapacheco, beneficiado de la parroquia de Santo Tomás de Vejoris y natural de esta localidad cántabra; y Juan Prestamero de Uribe, bachiller beneficiado de la parroquia de Santa María de Villacones de Añana ${ }^{36}$. A partir de ahí, la participación de las entidades religiosas en el diezmo es siempre inferior a las 50 fanegas. No podría decirse lo mismo de su participación en el situado, donde conventos y monasterios eran mayoría, si bien la institución más gravada era el Hospital del Rey de Burgos (tabla 6).

\section{TABLA 6: PROPIETARIOS DE ERAS GRAVADAS CON EL SITUADO (SEGUNDA MITAD DEL SIGLO XVIII)}

\begin{tabular}{|lrl}
\hline \multicolumn{1}{c}{ TitUlaR } & FANEGAS DE SITUADO \\
\hline Convento de San Juan de Acre de Añana & 7 \\
\hline Michaela de Tejada (Añana) & 12 \\
\hline Emeterio Corcuera (Añana) & 73 \\
\hline Joseph de Montoya (Añana) & 15 \\
\hline Francisca de Eguiluz (son del Cabildo) & 12 \\
\hline Hospital del Rey (Burgos) & 250 \\
\hline Colegiata de Covarrubias (Burgos) & 112 \\
\hline Convento de Santa María de Vadillo & 33 \\
\hline Monasterio de San Pedro de Cardeña (Burgos) & 166 \\
\hline Convento de Obarenes (Burgos) & 125 \\
\hline Monasterio de Valvanera (La Rioja) & 150 \\
\hline Convento de Santa María la Real de Vileña (Burgos) & 166 \\
\hline Monasterio de Nuestra Señora del Espino (Burgos) & 15 \\
\hline Monasterio de San Juan de Ortega (Burgos) & 180 \\
\hline Monasterio de San Miguel del Monte (Burgos) & 15 \\
\hline Monasterio de La Estrella (La Rioja) & 50 \\
\hline \multicolumn{1}{|c|}{ TOTAL } & 1.391 \\
\hline
\end{tabular}

En cualquier caso, estos datos sacan a la luz la extraordinaria vinculación que a esas alturas del siglo XVIII seguían teniendo los monasterios riojanos y burgaleses ligados desde la Edad Media con las salinas de Añana. Otros cenobios

36 ARCHV. Pleitos Civiles. Escribanía Zarandona y Wals. Pleitos Depositados. C 36/2 - L 23. (Años 1665-1673). 
en cambio han desaparecido de la lista, como San Pedro de Arlanza, San Millán de la Cogolla o Armentia y el convento de Santa María de Bujedo en Candepajares, bien porque se habían desprendido de sus eras o porque habían quedado subsumidos entre arrendatarios particulares, otros conventos, o tal vez la Hacienda Pública que era el caso de las eras de la Cogolla. Sin embargo, se han sumado conventos nuevos: el de las monjas cistercienses de Santa María la Real de Vileña, fundado en el siglo XIII por doña Urraca López de Haro esposa de Fernando II de León cerca de la villa de Barrios de Bureba, entre Briviesca y Poza de la Sal; el de San Juan de Acre, ya citado; y el de Santiago Vidijo cuya localización como convento no ha podido registrarse, si bien en la documentación de los siglos XVIII y XIX aparece siempre en la relación de los monasterios. En conjunto, las instituciones religiosas, ya seculares, ya regulares, contabilizaban 1.691,5 fanegas de diezmo-señor, lo que representaba el 40,96\% del total ${ }^{37}$.

\section{EL DIEZMO-SEÑOR Y LA DESAMORTIZACION ECLESIÁSTICA}

En los primeros cuarenta años del siglo XIX las salinas de Añana tuvieron que sortear muchos y muy serios problemas. Primeramente, una reforma de la infraestructura salinera que endeudó a los herederos y que no dio los resultados previstos $^{38}$, aunque permitió redactar una nueva contrata con la Corona en 1801 que autorizó un incremento tanto en el precio de fábrica - ahora a tres reales la fanega- como en el cupo $^{39}$. Poco tiempo después, a esta incierta

37 No se han contabilizado las fanegas de la cofradía de San Blas que las tenía el cabildo, ni las de los Argüelles que las tenían las monjas de San Juan de Acre, ni las de Plácido Humada que las tiene la iglesia de San Cristóbal.

38 En 1801 la Corona y la Comunidad de Herederos se pusieron de acuerdo en afrontar una seria remodelación de la infraestructura salinera, siguiendo los planes del comisionado regio, el arquitecto Manuel de La Vallina. Se trataba por supuesto de incrementar la producción -hasta 300.000 o 400.000 fanegas se proponían como posibles dada la fuerza del mineral salino- y de mejorar la sal en limpieza, blancura y salubridad. Hasta se pensó en modificar el método de fabricación, sustituyendo el tradicional de «a riego de cazuela o escudilla»o «de muera tirada» sobre suelo de arcilla, que era el que se empleaba tanto en Añana como en las salinas aledañas de Poza y Rosío, por el método llamado de «a lleno» y sobre suelos empedrados. Pero estos planes no dieron los resultados previstos y no consiguieron sino endeudar notablemente a los herederos, que llegaron a vender incluso algunos de sus bienes vinculados para arreglar las eras del Valle Salado. Total para luego apenas sacar rentabilidad a las reformas cuando menos hasta mediados de siglo. AHPA. Escribano Manuel de Olivares. Protocolo $n^{\circ} 9.833$, (año 1801).

39 Para abordar las obras, la Comunidad de Herederos y la Corona firmaron una nueva contrata que derogaba la que había permanecido vigente desde 1598. Por de pronto, se aseguraron de que aquella seguiría renovándoles el permiso para poder seguir usando el mineral salino. Y no sólo eso, sino que aceptó incrementarles el cupo anual hasta las 40.000 fanegas anuales y una subida en el precio de fábrica por primera vez en cien años, ahora a tres reales por fanega lo que suponía un incremento del $50 \%$. Por supuesto quedaban en pie los viejos gravámenes del diezmo-señor y situados, que los herederos se comprometían a pagar puntualmente. Más tarde, en 1814, la Corona 
aventura se sumarían los estragos de la guerra, primero la de la Independencia, después la primera de las carlistas. Aunque los franceses permanecieron en Álava desde 1807, fue en 1811 cuando comenzaron a acantonarse en Añana, parapetados en la iglesia de San Cristóbal ${ }^{40}$. La ocupación francesa pronto derivó en una fuerte subida de las demandas fiscales en toda la provincia para hacer frente a los gastos de la guerra. Las Juntas alavesas llegaron a contraer préstamos para aportar las cantidades precisas, e incluso hasta pensaron en intervenir parcialmente los bienes eclesiásticos e imponer contribuciones directas. De hecho, se recurrió a la enajenación de bienes comunales, y sobre todo del cle$\mathrm{ro}^{41}$, que fueron puestos en circulación mediante subastas a las que accedieron hacendados vitorianos que luego siguieron comprando este tipo de bienes en los sucesivos procesos de desamortización ${ }^{42}$, o de grupos de medianos propietarios, a veces asociados en el resto de la provincia. Pero se recurrió sobre todo a incrementar la fiscalidad indirecta, la que gravaba el consumo.

El devenir de la guerra entorpeció, y hasta paralizó, la producción de sal en Añana. También ésta cayó en las redes de la política de demandas fiscales, de suerte que desde principios de 1811 los herederos comenzaron a recibir peticiones de dinero del Gobierno francés, hasta superar los 27.000 reales $^{43}$. Aún así, los salineros hicieron esfuerzos por mantener su ritmo de fábrica y exigieron ayuda para reparar sus eras y poner en marcha el nuevo el proceso productivo, pidiendo un anticipo de más de 15.000 reales de vellón para los gastos preceptivos, el aumento de dos reales en el precio de fábrica y, como no, el perdón de las contribuciones acostumbradas, esto es, el diezmo y situado. Y a fe que los franceses aceptaron, estableciendo aquel en cinco reales por fanega, siempre y cuando la cosecha superase las 35.000 fanegas pues, de lo contrario,

autorizó la subida del precio de fábrica a 4 reales por fanega que fue el precio que se mantuvo en vigor hasta el desestanco. ATHA. Fondos Especiales. Salineros. Caja 9. Carp. $18 \mathrm{~s} / \mathrm{f}$.

40 Los franceses permanecieron en Álava entre 1807 y 1813. Como es sabido, a causa de su situación geográfica, las Provincias Vascas resultaron claves en el proyecto militar que Napoleón había planificado para toda la península. Por ello, mediante un decreto dictado en febrero de 1810, creó un Distrito de Gobierno Militar de Vizcaya que englobaba al País Vasco y Cantabria bajo el mando del General Thouvenot, que a la larga acabó ocupándose de toda la administración provincial bajo gobierno castrense. La capital de ese gobierno militar de Vizcaya se trasladó en 1811 a Vitoria, que pasó a ser el área de decisión política de toda la zona; Sobre la instalación de los franceses en Añana ATHA. Fondos Especiales. Documentación del Archivo Municipal de Salinas de Añana. Caja 19. Carp.1, f. 228 (Ayuntamiento de 16/XI/1811).

41 Dominguez Ortiz, Antonio: «Patrimonio y rentas de la Iglesia» en Artola, Miguel (Dir.): Enciclopedia de Historia de España, Madrid, 1988. Tomo 3, pág.116

42 Portillo, José María: «Entre revolución y tradición» en RIVERA, Antonio (Dir.): Historia de Álava, San Sebastián, 2003, págs. 334-335. Sobre la venta de comunales en tiempos del Gobierno francés, véase Porres MARIjuán, Rosario y BLAzQuez, Adrián: «Los bienes de Propios de la ciudad de Vitoria y su Jurisdicción en 1810», en IX Congreso de Estudios Vascos. Antecedentes próximos a la sociedad actual. Siglos XVIII y XIX, San Sebastián, 1984, pp. 495- 492.

43 ATHA. Fondos Especiales. Salineros. Caja 3. Carp. 2, f. 13 r. (26/IV/1811). 
se mantendría en vigor el precio estipulado en $1801^{44}$. Fue en todo caso agua de borrajas, al ser expulsado el ejército invasor en 1813.

Pero entre 1833 y 1839 de nuevo estalló la guerra, la primera de las carlistas, tras la crisis sucesoria planteada a la muerte de Fernando VII. En ese tiempo, la fábrica de Añana estuvo ocupada por los dos ejércitos contendientes y ambos usaron sus cosechas para su propio suministro. El resultado acabó siendo penoso. En la memoria que los herederos realizan en 1862 , se señala que en lo que llevaban de siglo la guerra había paralizado la producción al menos durante ocho años y, lo que es más importante, desde 1840 habían tenido que reedificar las dos terceras partes del Valle Salado a causa del mal estado en el que había quedado tras la carlista. Tenemos constancia, por lo demás, de que mientras duró la contienda el Ayuntamiento vendió diversos bienes municipales para hacer frente a los abastecimientos de las tropas que uno y otro bando reclamaron a la villa. Pero la guerra aún traería consigo otra consecuencia: la desamortización de los bienes del clero, entre otros las eras de fabricar sal.

Aunque con anterioridad ya se habían adoptado algunas medidas puntuales con el mismo fin en Álava, la verdadera rueda desamortizadora de los bienes eclesiásticos no comenzaría a rodar hasta las famosas Leyes de Mendizábal de 1836. Acuciado por la guerra carlista y los enormes agujeros de la deuda pública, el ministro de Hacienda dictó una serie de medidas que intentaron atajar de lleno el problema. Con ellas perseguía no sólo hacer frente a los gastos del Reino, sino desarrollar la idea liberal de la propiedad libre que llevara al máximo posible los beneficios, y construir una nueva base social para el nuevo régimen. En otras palabras, se extinguían las Órdenes religiosas y se nacionalizaban sus bienes, aplicándolos a dos objetivos principales: el pago de la deuda pública y los gastos de la guerra contra los carlistas. Había un tercer objetivo, apenas confesado: ampliar el número de simpatizantes del régimen liberal, al que ligarían su suerte todos los adquirientes de bienes desamortizados ${ }^{45}$. En realidad, se trató de despojar a la Iglesia de su patrimonio, consagrando la desaparición de los conventos y monasterios, asegurando eso sí, una decorosa sustentación del clero secular a cargo de la Corona. Al actuar así, tanto progresistas como moderados se movían por motivos ideológicos, políticos (el clero regular fue en su mayoría carlista mientras el secular fue isabelino) y económicos, puesto que el problema del déficit y de la deuda pública se mantenía, agravado por el estallido de la guerra civil y como no se quería aumentar de forma drástica la contribución de las demás clases, se estimaba que sólo una desamortización total de los bienes eclesiásticos podía aligerar, ya que no solucionar, el problema.

El 19 de febrero de 1836 se declararían ya en venta los bienes que habían pertenecido a corporaciones religiosas suprimidas. Unos pocos días después se redimían los censos a favor de comunidades monásticas y otros religiosos. En

44 Ibídem, f. $1 \mathrm{r}$.

45 Dominguez Ortiz, Antonio: «Patrimonio y rentas de la Iglesia», pág. 117. 
julio de 1837 se extinguían los monasterios, colegios, conventos, congregaciones y demás casas religiosas, así como sus diezmos y primicias ${ }^{46}$. En principio, parecía que el clero secular sería mejor tratado. No fue objeto de extinción como clase. Las iglesias permanecieron abiertas al culto, y sus riquezas artísticas y documentales fueron respetadas. Pero sus bienes raíces fueron objeto del mismo tratamiento que los del clero regular. No obstante, gobernando ya Espartero, varias leyes de 1841 dispusieron la venta de los bienes de catedrales, colegiatas, parroquias y ermitas en condiciones sumamente favorables para los compradores. Se trataba de llegar a un sistema de dotación eclesiástica, cuyas fuentes de financiación dependían de la nación porque, al haberse suprimido también el diezmo en 1837, el sostenimiento del culto y sus ministros sólo podía depender de las oblaciones de los fieles o del apoyo del Gobierno ${ }^{47}$.

Pero en las Provincias Vascas las cosas no eran tan sencillas. La ley de 29 de julio de 1837 no se aplicó, y cuando se publicó la de 1841 hubo que arbitrar medios para pagar al clero, ya que en las tres provincias la Corona no se hacía cargo de su mantenimiento, al menos de momento. En Álava el problema era aún mayor, pues por su tipo de poblamiento contaba con más pueblos que las vecinas y, por consiguiente, con más iglesias y beneficiados. Para pagar a un clero tan numeroso - un sacerdote por cada 105 almas escribiría un corresponsal de Madoz- y para mantener unos edificios religiosos tan abundantes, los pueblos alaveses decidieron seguir pagando el diezmo, sólo que en vez del 10 $\%$ pagaron el 7 e incluso el $5 \%$. El diezmo se aligeró, pero no desapareciót ${ }^{48}$.

La desamortización de las eras de sal se llevó a cabo en Añana en agosto de 1843 y afectó puntualmente a aquellas que venían perteneciendo al clero, que pasaron a la Hacienda Pública y más aún a manos particulares. No obstante, a la larga, la desamortización acabaría por repercutir sobre todos los propietarios, en la medida en que trastocó el montante global del diezmo-señor y situado al venderse poco después las eras desamortizadas libres de aquellas cargas. Y es que, aunque no se tratase propiamente de un diezmo eclesiástico, o al menos al uso, también el diezmo-señor de Añana se mantuvo en vigor, y lo hizo cuando menos hasta el año 1906, descontando los tercejones que no sobrevivieron a la ley del desestanco de 1869. Sin embargo, antes de entrar en ello, es importante

46 Martinez Ruiz, Enrique (Dir.): Diccionario de Historia Moderna de España. Vol. I. La Iglesia, Madrid, 1998, pág. 110.

47 En realidad se acabó utilizando una combinación de ambos sistemas. La Ley de Dotación de Culto y Clero de 14 de agosto de 1841, la fijaba en 105.406 .412 reales, aunque rebajaba de esa cifra 50 millones que se suponía producirían las fincas desamortizadas y no vendidas. Se contaba también con lo que producirían las oblaciones de los fieles y el importe de la Bula de la Cruzada, que en adelante no se computaría como un ingreso estatal. DomingueZ OrTIZ, Antonio: «Patrimonio y rentas de la Iglesia», p. 117.

48 Fernandez De PINEDO, Emiliano: Estudio introductorio al Diccionario Geográfico-EstadísticoHistórico de España y sus posesiones de ultramar de Pascual Madoz. Álava, Salamanca, 1989, págs. 22-23. 
saber si en $1842^{49}$ (tabla 7) algo había cambiado en relación con él desde la segunda mitad del siglo XVIII. Y efectivamente así había sido. A esas alturas del siglo XIX, la villa de Añana ha desaparecido ya de la relación del diezmo, cuando antes constaba con 17,5 fanegas. El mismo destino han seguido algunas instituciones religiosas como Covarrubias, La Estrella - a manos de la Hacienda Pública - y desde luego la iglesia de San Cristóbal de Añana destruida en plena guerra de la Independencia. A cambio, la otra parroquia de Añana, la de Villacones, había pasado de constar con 8 fanegas anuales a tener 140,5 . También el cabildo eclesiástico había logrado reforzar su presencia en el diezmo (de 126,5 pasa a 186,5 ), seguramente a costa de la cofradía de San Blas y el hospital de $A \tilde{n} a n a^{50}$. Las capellanías, salvo la de Contreras que había crecido ligeramente (de 112,5 a 128 fanegas), permanecían en el mismo estado, lo mismo que el conjunto de los particulares, con dos excepciones que en la relación de 1842 aparecen con inusitada fuerza: los Loma y los Paternina ${ }^{51}$. Finalmente, la Hacienda Pública aparecía por primera vez con un montante de 79 fanegas de diezmo-señor.

49 La relación de estos gravámenes corespondiente al año 1842 se recoge en dos documentos. El primero data del 1 de enero y en él se señalan los monasterios con el epígrafe «Monasterios, hoy el Crédito Público». La otra relación data del 17 de julio de ese mismo año y obedece a un «Acuerdo sobre rectificar la razón de las fanegas de Diezmo-Señor y Situado que deben pagar estos Herederos». Pero el contenido es similar al anterior. Ese documento comienza de la siguiente manera: «Habiendo notado que la razon de fanegas de sal de diezmo-señor y situado que obra en este libro maestro y debe pagar cada Heredero, no podia seguir en el dia tal y como se halla, porque gravando este impuesto por numero fijo de fanegas sobre determinadas granjas, estas en el transcurso de tanto tiempo habian mudado de dueños; acordó la Comunidad de Herederos en Junta celebrada el once de julio del corriente rectificarla con audiencia de los interesados (e intervención del Administrador representante de la Empresa Arriendo de sales en estas fabricas) y que hecha y aprobada por la Junta semejante operacion se traslade a este mismo libro una copia firmada por los Herederos o sus representantes además de otra que debe insertarse en el libro de actas para que en todo tiempo sirvan de norma en la distribucion de tales impuestos. Con cuyo objeto, reunidos en Junta en este dia, todos y la mayor parte de los ynteresados con la asistencia del dicho Señor Administrador de estas fabricas, se ha realizado aquella». ATHA. Fondos Especiales. Salineros. Caja 19. Carp. 28 (1/I/1842). ATHA. Fondos Especiales. Salineros. Caja 17. Carp. 1. Doc. 3 (17/VII/1842).

so La cofradía de San Blas desaparece en el listado de 1842 pero como en el anterior constaba que las llevaba el cabildo tal vez ahora han pasado a engrosar el montante de éste. También el hospital de Añana que aparecía con 11 fanegas, desaparece.

51 En la segunda mitad del siglo XVIII aparecen Francisco de Loma con 59 fanegas de diezmo aunque las lleva Lino Loma que lleva además otras 22 fanegas de Manuel de Fontecha y otras 97 propias, además de 10 pertenecientes al vínculo de Soto. En total 188 fanegas. En cambio, en la relación de 1842 sólo aparece un Loma, Manuel, que por sí sólo tiene 240,5 fanegas de diezmo más otras 6 por la era del convento del Vadillo. Mientras tanto, en esta última relación aparece por vez primera Ramón Paternina con 226,5 fanegas. 
TABLA 7: DIEZMO-SEÑOR Y SITUADO ANTES DE LA DESAMORTIZACION (AÑO 1842) (en fanegas)

\begin{tabular}{|c|c|c|c|}
\hline HEREDEROS & DIEZMO-SEÑOR & SITUADO & TOTAL \\
\hline Adrián de Herrán & 348,5 & - & 348,5 \\
\hline Hacienda Pública & 79 & 162 & 241 \\
\hline Cabildo Eclesiástico Añana & 186,5 & 12 & 198,5 \\
\hline Capellanía Contreras & 128 & - & 128 \\
\hline Capellanía Mata & 105 & - & 105 \\
\hline Capellanía o Patronato de Calderón & 128 & - & 128 \\
\hline Dario Hurtado de Corcuera & 456 & 75 & 531 \\
\hline Cayetano de Tejada & 58 & 12 & 70 \\
\hline Dionisio de Corcuera & 152,5 & - & 152,5 \\
\hline Curato de Añana & 3 & - & 3 \\
\hline Francisco Lechuga y Rubio & 34,5 & - & 34,5 \\
\hline Gabriel de Herrán & 178,5 & - & 178,5 \\
\hline Hospital del Rey de Burgos & 87,5 & 250 & 337,5 \\
\hline José de Luyando & 185,5 & - & 185,5 \\
\hline José Gonzalez Roldán & 354,5 & - & 354,5 \\
\hline José Montes y Villegas & 36,5 & - & 36,5 \\
\hline Galo Sáenz Valluerca & 44 & - & 44 \\
\hline Julián Marrón & 89,5 & - & 89,5 \\
\hline Iglesia de Añana & 140,5 & 7 & 147,5 \\
\hline Manuel de Loma, por sí & 240,5 & - & 240,5 \\
\hline Manuel de Loma por la era de Vadillo & 6 & 33 & 39 \\
\hline Manuel Argüelles & 165 & - & 165 \\
\hline Monjas de San Juan de Acre & 150 & 7 & 157 \\
\hline Matías de Unzueta & 24 & - & 24 \\
\hline Marqués de Ciriñuela & 107,5 & - & 107,5 \\
\hline Julián de Salazar & 49,5 & - & 49,5 \\
\hline Narciso Olarte & 36,5 & - & 36,5 \\
\hline Ponce y Bustamante & 47 & - & 47 \\
\hline Ramón Paternina & 226,5 & 15 & 241,5 \\
\hline Vínculo de Soto & 10 & - & 10 \\
\hline Convento del Espino & 76 & 15 & 91 \\
\hline Convento de San Juan de Ortega & 24 & 180 & 204 \\
\hline San Miguel del Monte/La Morcuera & 24 & 15 & 39 \\
\hline Santiago de Vidijo & 10 & - & 10 \\
\hline Valvanera & 32,5 & 150,5 & 183 \\
\hline Monjas de Vileña & 25 & 166 & 191 \\
\hline San Pedro de Cardeña & 36 & 166,5 & 202,5 \\
\hline Convento de Obarenes & 43,5 & 125 & 168,5 \\
\hline TOTAL & 4.129 & 1.391 & 5.520 \\
\hline
\end{tabular}


Pues bien, al aplicarse la desamortización el número total de granjas enajenadas fue de 50, que fueron vendidas después por 265.373 reales de vellón ${ }^{52}$. Si aceptamos que cada granja la componían unas 20 eras, el resultado es que las enajenadas fueron unas 1.000 o, lo que es lo mismo, el 22,72\% del total de las 4.400 que por entonces componían en Valle Salados3. Sin embargo, como se ha dicho, el proceso desamortizador acabó afectando al conjunto de los herederos propietarios de las salinas.

\section{TABla 8: GRAVAMENES DE LAS SALINAS AFECTADAS POR LA DESAMOR- TIZACION. CLERO SECULAR (en fanegas)}

\begin{tabular}{|lc|c|c|}
\hline INSTITUCION & DIEZMO-SEÑOR & SITUADO & TOTAL \\
\hline Cabildo Eclesiástico de Añana & 186,5 & 12 & 198,5 \\
\hline Santa María de Villacones de Añana & 140,5 & 7 & 147,5 \\
\hline Curato de Añana & 3 & - & 3 \\
\hline \multicolumn{1}{r|}{ TOTAL } & 330 & 19 & 349 \\
\hline
\end{tabular}

\section{TABLA 9: GRAVAMENES DE LAS SALINAS AFECTADAS POR LA DESAMORTI- ZACION. CLERO REGULAR (en fanegas)}

\begin{tabular}{|c|c|c|c|}
\hline INSTITUCIÓN & DIEZMO-SEÑOR & SITUADO & TOTAL \\
\hline Convento de San Juan de Acre de Añana & 150 & 7 & 157 \\
\hline Convento del Espino & 76 & 15 & 91 \\
\hline Convento de San Juan de Ortega & 24 & 180 & 204 \\
\hline San Miguel del Monte/La Morcuera & 24 & 15 & 39 \\
\hline Santiago de Vidijo & 10 & - & 10 \\
\hline Monasterio de Valvanera & 32,5 & 150,5 & 183 \\
\hline Santa María la Real de Vileña & 25 & 166 & 191 \\
\hline San Pedro de Cardeña & 36 & 166,5 & 202,5 \\
\hline Convento de Obarenes & 43,5 & 125 & 168,5 \\
\hline TOTAL & 421 & 825 & 1.246 \\
\hline
\end{tabular}

52 De ellas, 27 pertenecían al clero secular, 13 al clero regular masculino y 10 al regular femenino. Motiloa PoZa, José María: Desamortización, fueros y pronunciamientos en el siglo XIX, Vitoria, 1975.

53 Según reflejan los herederos en el siglo XIX cada granja se componía de veinte, treinta o más eras, aunque, por ejemplo se ha constatado que las 194 eras de la Hacienda eran computadas en diez granjas. Memoria de las fábricas de las salinas de Añana. Vitoria, 1862, pág. 7. No obstante, el número consignado coincide con las proporciones que otras fuentes documentales adjudican a la propiedad de eras del clero. 
La desamortización redujo el diezmo-señor en 751 fanegas (tablas 8 y 9), quedando en 3.378 fanegas anuales a partir de 1846 (Véase tabla 10). No obstante, en conjunto, las salinas que entonces perdió el clero estaban gravadas con 1.595 fanegas, cuyo montante repercutirá desde entonces, en el cómputo global del diezmo señor y situados que anualmente debían abonar desde Añana a la Corona. Además, un tiempo después a esa rebaja se sumó otra de 241 fanegas anuales con las que se hallaban gravadas unas eras que en 1842 Hacienda había comprado a don Juan Manuel de Corcuera y al convento de La Estrella, en la localidad riojana de San Asensio ${ }^{54}$. En total, los Herederos vieron rebajar el montante anual que en concepto de diezmo-señor y situados debían pagar a la Corona en un $36,71 \%$, quedando reducido apenas a 3.165 fanegas (hasta entonces habían sido 5.001). Eso sí, el valor de los tercejones se mantuvo intacto, lo que quiere decir que las cargas globales que los herederos de Añana soportaron en adelante ascendieron a 3.684 fanegas anuales en lugar de las 5.520 que habían venido abonando hasta entonces (un 32,26\% menos) ) $^{55}$.

De las eras desamortizadas se beneficiaron vecinos de la villa. Algunas fuentes señalan que fueron tres los herederos de la Comunidad de Añana en quedarse con ellas: Nicanor Velandia, Luis Orive y Gabriel Herrán. Pero comparando la relación del diezmo-señor y situados del año 1842 con la realizada en 1845 , esto es, el antes y el después de la desamortización, y a su vez cotejando el resultado con otra relación efectuada en 1846, se deduce que no fueron los únicos. Sin ninguna duda, el mayor comprador fue Velandia, que con anterioridad no disfrutaba sino de algunas salinas pertenecientes a la capellanía de Mata y que a partir de 1845 figura con un gravamen de 553 fanegas y media. Debió seguirle en orden Luis Orive, con 349 fanegas, mientras que el caso de Gabriel de Herrán resulta más complejo de computar, puesto que en 1842 aparece con 178,5 de diezmo-señor, que en la nueva relación queda reducido a 38,5 , aunque en 1845 computa 100 fanegas de situado que antes no aparecí$\mathrm{an}^{56}$. Esta última circunstancia nos indica que, efectivamente, debió hacerse con las salinas de alguno de los conventos desamortizados. Aunque no resulta fácil convertir estos datos en eras, es posible que el número de eras adquiridas por Velandia se acercase a las 435 y las de Orive a las 275.

54 Las eras compradas a Corcuera estaban gravadas con 72 fanegas de diezmo señor y 112 de situado, y las de la Estrella lo estaban con 7 y 50 respectivamente. Todas ellas componían el total de 241 fanegas. ATHA. Caja 19. Carp. 28 (1/I/1842).

55 Cierto es, no obstante, que esa rebaja no se llevaría a cabo hasta el año 1846, en el que hubo que recordar a Hacienda que las salinas del clero «se vendieron libres de toda carga por la Nación en el año 1844, quedó suprimido este gravámen (se refiere al diezmo-señor y situados) por real orden de 1846 a instancia de los compradores Memoria de la Fábrica.., pág. 29.

56 En total pierde 40 fanegas entre una fecha y otra puesto que en 1842 sus salinas se hallaban gravadas con un total de 178,5 y en 1845 apenas lo estará con 138,5 . 


\section{TABla 10: GRAVAMENES DE las SALINAS DE AÑANA DESPUES DE LA DESA- MORTIZACION (AÑO 1845) 57}

\begin{tabular}{|c|c|c|c|}
\hline HEREDEROS & DIEZMO-SEÑOR & SITUADO & TOTAL \\
\hline El Espíritu Santo & - & - & - \\
\hline José de Bonifaz & - & - & - \\
\hline Manuel de Argüelles & 165 & $138 / 6$ & $303 / 6$ \\
\hline Bustamante & 47 & & 47 \\
\hline Darío de Corcuera & 456 & 75 & 531 \\
\hline Calderón Escalante & 128 & - & 128 \\
\hline Empresa Salamanca & 79 & 162 & 241 \\
\hline GREGORIO HERRAN* & $178 / 6$ & - & $178 / 6$ \\
\hline GABRIEL HERRAN & $38 / 6$ & 100 & $138 / 6$ \\
\hline Adrián Herrán & $348 / 6$ & - & $348 / 6$ \\
\hline Hospital del Rey de Burgos & $87 / 6$ & 250 & $337 / 6$ \\
\hline Manuel Marrón & $89 / 6$ & - & $89 / 6$ \\
\hline Montes y Villegas & $36 / 6$ & - & $36 / 6$ \\
\hline Manuel Loma & $240 / 6$ & $138 / 6$ & 379 \\
\hline José Luyando & $185 / 6$ & - & $185 / 6$ \\
\hline Alejo Olarte & $36 / 6$ & - & $36 / 6$ \\
\hline LUIS ORIVE & 330 & 19 & 349 \\
\hline N.Paternina & $226 / 6$ & 15 & $241 / 6$ \\
\hline José Roldán & $354 / 6$ & - & $354 / 6$ \\
\hline Rubio lechuga & $34 / 6$ & - & $34 / 6$ \\
\hline Julián de Salazar & $49 / 6$ & - & $49 / 6$ \\
\hline Vínculo de Soto & 10 & - & 10 \\
\hline Galo Valluerca & 44 & - & 44 \\
\hline Marqués de Ciriñuela & $107 / 6$ & - & $107 / 6$ \\
\hline Matías Unzueta & 24 & - & 24 \\
\hline ANDRES URETA & 100 & 177 & 277 \\
\hline Cayetano Tejada & 58 & 12 & 70 \\
\hline Santa María del Vadillo & 6 & 33 & 39 \\
\hline Francisco de Corcuera & $152 / 6$ & - & $152 / 6$ \\
\hline NICANOR VELANDIA & 200 & $353 / 6$ & $553 / 6$ \\
\hline Luis Beltrán de Salazar (1) & $26 / 3$ & - & $26 / 3$ \\
\hline Francisco Corcuera (1) & $26 / 3$ & - & $26 / 3$ \\
\hline Nicanor Velandia (1) & $26 / 3$ & - & $26 / 3$ \\
\hline
\end{tabular}

57 ATHA. Fondos Especiales. Salineros. Caja 19. Carp. 30, ff. 3r-v. 


\begin{tabular}{|c|c|c|c|}
\hline HEREDEROS & DIEZMO-SEÑOR & SITUADO & TOTAL \\
\hline Nicanor Velandia y Benito Angulo (1) & $26 / 3$ & - & $26 / 3$ \\
\hline $\begin{array}{l}\text { Juana y Bernardina Angulo y Anastasia } \\
\text { Díaz de Tuesta (2) }\end{array}$ & $40 / 6$ & - & $40 / 6$ \\
\hline Benito Angulo y Feliciana Urizar (2) & $31 / 8$ & - & $31 / 8$ \\
\hline Francisca Anuncibay y Joaquín Aranguiz (2) & 15 & - & 15 \\
\hline $\begin{array}{l}\text { Julián Guinea, Manuel Angulo y Pedro Díaz } \\
\text { de Tuesta (2) }\end{array}$ & $40 / 10$ & - & $40 / 10$ \\
\hline TOTAL & $4.046,5$ & $1.473,5$ & 5.520 \\
\hline
\end{tabular}

* Los datos consignados en negrita indican las novedades respecto a la tabla de 1842 , novedades que se suman, por supuesto, a la desaparición de los conventos y demás instituciones eclesiásticas.

(1) Capellanía de Mata.

(2) Capellanía de Contreras.

Ahora bien, de la relación de 1845 se puede colegir que debió haber seguramente otros compradores además de los señalados. Para empezar, Andrés Ureta, que aparece como nuevo propietario en 1845 con 100 fanegas de diezmo y 177 de situados. Mientras tanto, Manuel de Argüelles y Manuel de Loma, que ya eran propietarios de salinas gravadas con el diezmo, aparecen ahora con 138 fanegas y media respectivamente en el apartado de los situados, lo cual prueba que, efectivamente se han hecho con salinas del clero. Y, como decíamos, hay aún otro dato que confirma nuestras sospechas. Cuando en 1846 se recuerda a la Hacienda que esas salinas han sido compradas sin los gravámenes correspondientes y que por esa razón se les deben rebajar, aquellos desaparecen en la relación (tabla 11) ${ }^{58}$. Entre todos ellos suman unos gravámenes nuevos de $1.556,5$ fanegas ${ }^{59}$.

58 En efecto, se ha podido comprobar que en la relación del diezmo-señor y situados de 1846 , esos gravámenes les han sido descontados. A todos excepto a Gregorio de Herrán, que entra como nuevo propietario en la lista de 1845 con 178 fanegas y media de gravámenes y que sin embargo se le conservarán, lo cual indica que no se trataba de salinas pertenecientes al clero. ATHA. Fondos Especiales. Salineros. Caja 17. Carp. 1. Doc. 4. ff. 41v. 42r, (Añana, 14/XI/1846).

59 Sin incluir las de Gregorio de Herrán. Por lo demás, y salvo los cambios consignados, los datos comparativos entre 1842 y 1845 indican que todo permaneció igual aunque, por primera vez, los de este último año nos aportan datos puntuales sobre los participantes en las capellanías de Mata y Contreras. 
TABLA 11: DIEZMO-SEÑOR Y SITUADOS DESPUÉS DE LA DESAMORTIZACIÓN (en fanegas) (AÑo 1846)

\begin{tabular}{|c|c|c|c|}
\hline HEREDEROS & DIEZMO-SEÑOR & SITUADO & TOTAL \\
\hline Manuel Félix de Argüelles & 165 & - & 165 \\
\hline José Bonifaz & - & - & - \\
\hline Eugenio Corcuera & 47 & - & 47 \\
\hline Cornelio Escalante (Capellanía Calderón) & 128 & - & 128 \\
\hline Poseedores Capellanía Contreras & 128 & - & 128 \\
\hline Poseedores Capellanía Mata & 105 & - & 105 \\
\hline Francisco Corcuera & 152,5 & - & 152,5 \\
\hline Darío Corcuera & 456 & 75 & 531 \\
\hline Espíritu Santo & - & - & - \\
\hline Adrián de Herrán & 348,5 & - & 348,5 \\
\hline Gregorio de Herrán & 178,5 & - & 178,5 \\
\hline Gabriel de Herrán & 10 & - & - \\
\hline Hospital de Burgos & 87,5 & 250 & 337,5 \\
\hline Manuel Marrón & 89,5 & - & 89,5 \\
\hline José Montes y Villegas & 36,5 & - & 36,5 \\
\hline Manuel de Loma & 240,5 & - & 240,5 \\
\hline José Luyando & 185,5 & - & 185,5 \\
\hline Alejo Olarte & 36,5 & - & 36,5 \\
\hline Luis Orive & - & - & - \\
\hline Eduardo Paternina & 226,5 & 15 & 241,5 \\
\hline José Roldán & 354,5 & - & 354,5 \\
\hline Rubio Lechuga & 34,5 & - & 34,5 \\
\hline Julián Salazar & 49,5 & - & 49,5 \\
\hline Vinculo de Soto & 10 & - & 10 \\
\hline Galo Saenz de Valluerca & 44 & - & 44 \\
\hline Nicanor Velandia & - & - & - \\
\hline Matías Unzueta & 24 & - & 24 \\
\hline Andrés Ureta & - & - & - \\
\hline Vadillo & 6 & 33 & 39 \\
\hline La Hacienda / Empresa Salamanca & 79 & 162 & 241 \\
\hline Marqués de Ciriñuela & 107,5 & - & 107,5 \\
\hline Isidora del Castillo & - & - & - \\
\hline Cayetano de Tejada & 58 & 12 & 70 \\
\hline TOTAL & 3.378 & 547 & 3.925 \\
\hline
\end{tabular}




\section{EL DIEZMO-SEÑOR TRAS LA LEY DEL DESESTANCO DE 1869}

Tampoco la ley de 16 de junio de 1869, que declaraba libres la fabricación y venta de la sal desapareciendo por consiguiente el estanco y el monopolio ejercido hasta entonces por la Monarquía, acabó con el diezmo-señor ${ }^{60}$. Ciertamente, la nueva ley amenazó con poner fin a ese peculiar modo de organizarse que las salinas de Añana habían mantenido desde 1564. Así que, como siempre que se aproximaban cambios, una vez más la incertidumbre se apoderó de los herederos. Abogaron por mantener la costumbre en todo lo referente a la producción pero, sobre todo, se preguntaron si se respetarían sus derechos sobre las mueras y las condiciones establecidas con la hacienda hasta entonces. Para ello la Comunidad se dirigió a la Dirección General de Propiedades y Derechos del Estado tratando de asegurar para los herederos la continuidad en el funcionamiento de sus fábricas de sal. Después de varias gestiones e incidentes — según relata la documentación - y de haber sido facultados por orden del regente del reino en 27 de mayo de 1870 para dar comienzo a la nueva campaña con las condiciones acostumbradas, en el mes de noviembre el oficial letrado de la Administración Económica de Burgos planteó la conveniencia de que se redimiera el canon del diezmo-señor que aseguraba a los salineros de Añana la continuidad en la explotación de las fuentes minerales de la villa ${ }^{61}$. Era un primer aviso, una primera amenaza que volvería a repetirse unos años después, una vez superada la nueva contienda carlista.

Toda prudencia era poca en aquella etapa de incertidumbres. ¿Se les permitiría seguir abonando el diezmo-señor? ¿Sería suficiente éste para mantener el usufructo de las mueras?. En definitiva, ¿qué planes tenía la Hacienda Pública para las salinas de Añana?. Ni la prudencia ni los recelos estuvieron de más, porque durante los ocho años siguientes los herederos tuvieron que vivir en la más absoluta de las nebulosas. Primero, porque en los dos primeros que siguieron al desestanco la Administración no dio respuesta certera a aquellas cuestiones, ni a la propuesta del oficial letrado de la Administración Económica de Burgos. Por eso respiraron tranquilos cuando al cabo de muchos meses pudieron abonar el montante del canon correspondiente a los años 1870-1871, y reanudar la fabricación de la sal a comienzos del verano del año siguiente. Claro que, para entonces el valor del diezmo-señor y situado había sufrido una ligera modificación como consecuencia de la venta de las llamadas «eras del Vadillo» esto es, las pertenencientes al convento de Santa María del Vadillo gravadas con 39 fanegas anuales. No sabemos la fecha exacta en la que ese hecho tuvo lugar, pero datos indirectos nos indican que hubo de ser entre 1863 y 1870 . De ese modo, el montante global de las cargas que los herederos debían soportar pasó de 3.684 a 3.645 fanegas anuales. No obstante, parece ser que a partir de 1870 desaparecieron los tercejones, con lo cual la carga de los herederos quedó reducida a 3.126 fanegas anuales ${ }^{62}$.

60 ATHA. Fondos Especiales. Salineros. Caja 3. Carp. 2, ff. 214 r.-215v.

61 ATHA. Fondos Especiales. Salineros. Caja 7. Carp. 46, f. 17v y 21 r.

62 ATHA. Fondos Especiales. Salineros. Caja 19. Carp. 30, sin foliar (año 1870). 
TABLA 12: REPARTO DEL DIEZMO-SEÑOR Y SITUADO TRAS LA DESAPARICIÓN DE LOS TERCEJONES (AÑO 1870).

\begin{tabular}{|c|c|c|c|}
\hline HEREDERO & $\begin{array}{l}\text { PAGABA ANTES } \\
\text { fanegas }\end{array}$ & $\begin{array}{l}\text { PAGARÁ AHORA } \\
\text { fanegas }\end{array}$ & $\begin{array}{l}\text { IMPORTE A } 4 \text { r/f } \\
\text { reales }\end{array}$ \\
\hline Adrián Herrán & $348 / 6$ & 297 & 1.188 \\
\hline Antonio Salazar & $49 / 6$ & $42 / 6$ & 170 \\
\hline Bernardo Cazaña & 531 & $455 / 8$ & $1.822,67$ \\
\hline Castor Corcuera & $178 / 9$ & $153 / 2$ & 612,64 \\
\hline Cornelio Escalante & 128 & $109 / 9$ & 439 \\
\hline Eugenio Corcuera & 47 & $40 / 4$ & 161,30 \\
\hline Eduardo Paternina & $241 / 6$ & $207 / 3$ & 829 \\
\hline Eusebio Sagarmínaga & “ & “ & “ \\
\hline Francisco Lechuga & $34 / 6$ & $29 / 8$ & 118,68 \\
\hline Gabriel Herrán & $188 / 6$ & $161 / 9$ & 647 \\
\hline Gregorio Herrán & $13 / 1$ & $11 / 3$ & 45 \\
\hline Gregoria Argüelles & 108 & $92 / 8$ & 370,67 \\
\hline Hospital de Burgos & $337 / 6$ & $289 / 8$ & $1.158,67$ \\
\hline Ignacio $M^{a}$ Arevalo & $92 / 6$ & $79 / 5$ & 317,64 \\
\hline Juliana Ocharan & 44 & $37 / 9$ & 151 \\
\hline José Villegas & $36 / 6$ & $31 / 6$ & 126 \\
\hline José Roldán & $354 / 6$ & $304 / 3$ & 1.217 \\
\hline José Serrada & $11 / 6$ & $9 / 11$ & 39,64 \\
\hline José Angulo & $52 / 10$ & $45 / 3$ & 181 \\
\hline Juan Cruz de Unzueta & 24 & $20 / 8$ & 82,67 \\
\hline Marcelino R. Huidobro & $36 / 6$ & $31 / 6$ & 126 \\
\hline Manuel Marrón & $89 / 6$ & $76 / 9$ & 307 \\
\hline Marqués Montesacro & 93 & $79 / 9$ & 319 \\
\hline Marqués de Ciriñuela & $107 / 6$ & $92 / 3$ & 369 \\
\hline Manuel de Loma & $132 / 6$ & $113 / 9$ & 455 \\
\hline Manuela R. Arbulo & $46 / 10$ & $40 / 1$ & 160,30 \\
\hline Manuel Guinea & $26 / 3$ & $22 / 9$ & 91 \\
\hline Pedro Egaña & $23 / 4$ & $20 / 2$ & 80,64 \\
\hline Ramón de Argüelles & 145 & $124 / 4$ & 497,30 \\
\hline Rafael Tejada & 70 & 60 & 240 \\
\hline Sandalio Mz. de la Pera & $32 / 10$ & $28 / 2$ & 112,64 \\
\hline Vicente Argüelles & 20 & $17 / 2$ & 68,64 \\
\hline TOTAL & 3.645 & 3.126 & 12.504 \\
\hline
\end{tabular}


Pero eran aquellos tiempos convulsos a causa una vez más de la guerra, de nuevo la carlista (1872-1876), suscitada tras la revolución de septiembre de 1868 que derrocó a Isabel II. Esta vez, además, la implicación de la población convirtió a las Provincias Vascas en el escenario bélico principal. Desde el verano de 1873 las tropas carlistas se asentaron de forma permanente en Salinas de Añana, donde «dispusieron a su arbitrio no solo de las rentas de los liberales emigrados, sino de las sales de todos los propietarios inclusas las pertenecientes al Estado, y por la fuerza» ${ }^{63}$. Sólo el final de la guerra, en febrero de 1876, cuando Carlos VII cruzó la frontera camino de Francia pronunciando su famoso ivolveréi, puso fin a esta situación ${ }^{64}$. Pero para la villa alavesa los problemas no habían hecho más que empezar. Interrumpido en toda esa etapa el pago del diezmo-señor y situado a la Hacienda Pública por las confiscaciones de los carlistas, es probable que aquella tratase de aprovechar la coyuntura para de una vez por todas enajenar las salinas y desmontar el sistema que venía funcionando desde 1564 .

Lo cierto es que en 1877 los herederos se encontraron con una desagradable sorpresa. En el Boletín Oficial de la Provincia de Álava número 36 correspondiente al 1 de agosto, se anunciaba la venta en subasta pública para el 12 de octubre de la «salinería y demás fincas sitas en el pueblo de Añana que procedan del Estado» ${ }^{65}$. Aparentemente nada había de particular porque, en efecto, la Hacienda Pública poseía todavía unas 194 eras y otras fincas legalmente enajenables ${ }^{66}$. Pero sí había una novedad, y preocupante. En el anuncio se insertaba una memoria descriptiva de las salinas que por orden de la Administración había efectuado el ingeniero Castor de Vivanco quien, a la hora de tasar el valor de las mismas, había incluido no sólo las eras de propiedad estatal sino las

63 ATHA. Fondos Especiales. Salineros. Caja 7. Carp. 46, ff. 6r-v.

64 Aunque 1874 fue el año del apogeo carlista, el carlismo careció de fuerza para imponerse definitivamente. La restauración de los Borbones en la persona de Alfonso XII (31 de diciembre de 1874) significó un golpe moral para la causa del pretendiente. Muchos de los que habían venido a sus filas tras la revolución de 1868 , pudieron regresar ahora a la obediencia del nuevo rey que se les aparecía como el retorno a la vieja legalidad. Tras sucesivos reveses militares, Carlos VII cruzó la frontera francesa por Dancharinea el 28 de febrero de 1876 tras aquel famoso ivolveréi que nunca habría de cumplirse.

65 En realidad la sorpresa no había sido tanta porque, antes de insertar la convocatoria en el Boletín, la Administración Económica de la Provincia de Álava había avisado de ello a la Comunidad de Herederos, al tiempo que por carta de 20 de julio de 1877 les pedía referencia sobre el «estado jurídico» en el que se hallaban las salinas. Publicada ya la convocatoria, y tras remitir la Comunidad un primer informe el día 12 de agosto, al día siguiente la Administración Económica de Álava declaró «carecer de atribuciones para suspender la tramitación de la venta de las salinas», animándoles a que recurrieran a la Dirección General del ramo, razón por la cual los Herederos tramitaron desde entonces las cuestión ante el Director General de Propiedades y Derechos del Estado. ATHA. Fondos Especiales. Salineros. Caja 7. Carp. 46, ff. 7r-8r.

66 Los bienes que por entonces poseía la Hacienda Pública en Añana eran: 19 granjas (194 eras) de cristalización con sus pozos y terrazos, tres almacenes para la sal, dos parcelas de terreno baldío y el uso y disfrute de un caudal de agua salífera correspondiente a las 194 eras. A ello se añadía, por su puesto, el cobro del diezmo-señor y situados. ATHA. Fondos Especiales. Salineros. Caja 19. Carp. 49, f. 6r. 
de todos los propietarios y, lo que era aún peor, también el valor de las «fuentes minerales», adjudicando a todo ello un valor de 1.644 .736 pesetas. Esa sería la cantidad que habría de servir como tipo de referencia en la subasta. Fue esta circunstancia la que indujo a los herederos a pensar que se trataba de vender las fuentes de las mueras. Sospecha razonable si se atiende a que el ingeniero había capitalizado el valor de las mismas en 1.579 .222 pesetas o, lo que es lo mismo, el $96 \%$ del valor de lo tasado. Para colmo de males, en su aserto el señor Vivanco sacaba a relucir un tema, nada nuevo desde luego pero si inquietante, cual era el de la infrautilización de las riquísimas mueras de Añana por parte de los herederos, tanto por las que se perdían en la época de fábrica, cuanto por las que no se utilizaban entre los meses de enero y abril y que, en su opinión, daban como para añadir a aquel valor otras 128.526 pesetas más y para alcanzar una producción medida en otras tantas fanegas de sal.

La Comunidad vio en aquellos momentos peligrar como nunca hasta entonces la industria que durante más de ocho siglos había venido manteniendo a la villa. Por eso, el 30 de septiembre de aquel mismo año de 1877 solicitaron al Director General de Propiedades y Derechos del Estado que la subasta programada para el día 12 de octubre fuera suspendida. No obstante, aunque ésta no llegó a celebrarse en el plazo establecido, aquel decidió seguir adelante con la venta. En esa tesitura, en el mes de diciembre la Comunidad -con el respaldo del Administrador Económico de la Provincia de la Álava- decidió elevar recurso de alzada ante el Ministro de Hacienda.

Varias eran las cuestiones que descolocaban a los herederos en aquel asunto. Si como se les venía reconociendo desde hacía siglos eran propietarios de sus granjas y sus eras y a través del diezmo-señor tenían el derecho de uso exclusivo y permanente de las mueras iqué derecho tenía el ingeniero Vivanco a tasar nada que no fuera la salinería real compuesta por las 194 eras que tenía la Hacienda Pública con sus almacenes y demás artefactos que le servían cuando las sales estaban estancadas y que era lo único legalmente en disposición de venderse ?. Por otro lado, si la Comunidad no había solicitado la redención del diezmo-señor, y la vigencia de éste sólo dejaba a la Corona el dominio directo sobre las mueras pero no el usufructo equé era lo que quedaba por vender la Corona de las fuentes salinas? ¿Acaso el propio canon del diezmo-señor «que es el que representa el dominio alto, eminente, directo, único», aunque no la capacidad de explotar las mueras? ${ }^{37}$ ¿Estaba tratando la Corona de romper unilateralmente el contrato enfitéutico y de desarticular el sistema que a través de aquel canon había regulado la participación de la Comunidad de Herederos en el negocio de la sal en Añana cuando menos desde el siglo XVI?.

De lo que no tenían duda era de que en la memoria y tasación del ingeniero «se pintaban imaginarios recursos para el Erario Público» ${ }^{68}$. Aunque mejo-

67 ATHA. Fondos Especiales. Salineros. Caja 7. Carp. 46, f. 18 r.

68 Ibídem, f. 11r. Ibídem, f. 13v. 
rando el aprovechamiento de las mueras lograran incrementar la producción en un tercio, jamás se podrían alcanzar las más de 125.000 fanegas que proponía Vivanco, sino como mucho unas $70.000^{69}$. Y además, de lograrse un mayor rendimiento de las mueras ique hacía pensar al ingeniero que el beneficio debía ser para la Hacienda Pública?. He aquí una cuestión que no era nueva: ¿A quien pertenecían las mueras sobrantes?. La Administración parecía presumir que todo el aumento de agua que recibiesen los manantiales «por el acaso o por nuevas obras» le pertenecía, sin que los herederos pudiesen reclamar su propiedad. Pero los argumentos del representante de la Comunidad parecían presumir todo lo contrario:

«El primer estremo de esta proposicion no puede negarse, supuesto se ha reconocido y se reconoce en el Estado el dominio directo de los minerales, produzcan mas o produzcan menos mueras, como ha sucedido esto ultimo desde mediados del presente siglo en que por efecto de obras necesarias (se refiere a las dirigidas por José Plaza) disminuyeron las fuentes en más de una quinta parte de su caudal antiguo que desde entonces a nadie se le haya ocurrido dudar a quien pertenezia esta perdida de mueras, si al que tiene y paga el uso de ellas, o sea el dueño del útil, o a el Estado que cobra siempre por igual el canon, lo mismo que se fabriquen diez mil fanegas que cien mil, como de uno y otro han existido repetidos ejemplos; pero en lo que no cabe conformidad es en el otro extremo de que los herederos no tendrian derecho a reclamar la propiedad del aumento. ¿Y por qué no puesto que el derecho lo tienen al uso total y esclusivo de las mueras de las fuentes y puesto que el canon o pensión que pagan es por todas ellas y siempre igual sin regularlo a la cantidad de agua salobre que utilicen los enfiteutas o pensionistas?; de lo que se sigue al propio tiempo que tampoco es exacta la segunda parte en que se sienta que cuando en ciertas épocas no se elavora sal pertenezca también el aumento o mas bien sobrante de mueras al estado a no ser en los términos esplicados» 70

Aprobada la ley de 11 de julio de 1878 sobre redención de censos, la cuestión del canon entró en un nuevo foro de discusión, cual era saber si dada su naturaleza podía redimirse o no. Durante un tiempo, gracias a la lentitud de la burocracia, la Comunidad logró salvar el escollo y mantener en vigor el pago del diezmo y situado, que en 1883 pasó de 3.126 fanegas a 2.836, y en realidad a su equivalente en pesetas, esto es, 2.836 pesetas y 33 céntimos, después de que Hacienda enajenase las eras del Hospital de Burgos que estaban gravadas con 289 fanegas y 8 celemines $^{71}$. Fue entonces cuando aquel justificó su acción alegando que «mediante las diferencias que separan esta propiedad de

69 Según el representante de la Comunidad de Herederos, en aquella etapa se venían fabricando como media unas 50.000 fanegas, y de aumentarse un tercio a través del mejor aprovechamiento de las mueras no podrían producirse sino entre 66.000 y 70.000 fanegas anuales.

70 ATHA. Fondos Especiales. Salineros. Caja 7. Carp. 46, f. 16r, (8/XII/1877).

71 ATHA. Fondos Especiales. Salineros. Caja 7. Carp. 10, ff. 24-25. 
las demás que son objeto de las leyes desamortizadoras no cabe aplicar al mineral salinero las disposiciones de estas relativas a las redenciones, sino enajenar sus derechos de propiedad en el manantial con las limitaciones que constituyen los de los herederos a la cantidad de mueras en el tiempo y condiciones que les están otorgados» ${ }^{72}$. No es de extrañar que poco después, por real orden de 8 de julio de 1882, se sirviera disponer que aquellos no tenían el dominio útil sobre el manantial salobre, sino el mero derecho de usar de sus productos mediante el pago de un canon y que este derecho «no era de aquellos a los que por su naturaleza pudieran aplicarse las disposiciones relativas a la redención de cargas que afectan a la propiedad del Estado», razón por la cual desestimaba el recurso de alzada interpuesto por don Castor de Corcuera y confirmaba en sus extremos el acuerdo apelado. Las cosas volvían a estar, por tanto, como en 1877.

Pero en el otoño de 1905, (real orden 10 de noviembre) el Ministro de Hacienda ofreció a la Comunidad de Herederos la posibilidad de redimir el canon del diezmo-señor y situados, esta vez sí, ateniéndose a la ley de 11 de julio de 1878 sobre redención de censos. Este cambio de actitud por parte de las autoridades estatales obedeció a la necesidad de «allanar las dificultades que se oponen a la venta de las salinas de Añana». El último arriendo de las posesiones de la Hacienda Pública en la villa había finalizado en diciembre de 1889 y, aunque las había sacado a subasta pública en numerosas ocasiones, nunca había podido volver a arrendarlas por falta de postor. El motivo era lo que la propia Dirección General de Contribuciones, Impuestos y Rentas definía como la disputa que sobre las salinas mantenían Hacienda y la Comunidad. De esta suerte, el 18 de agosto de 1902 Hacienda decidió sacarlas a la venta. Pero celebradas las correspondientes subastas sin que compareciera licitador — en 1905 seguían en «subasta abierta»- se optó por buscar otras vías. Las autoridades seguían atribuyendo el escaso resultado de las subastas a la forma en la que venían utilizándose las salinas «y el cuidado que inspiran a las personas que desean adquirirlas la Comunidad de Herederos copartícipes con el Estado en los derechos a las mismas». Pero lo achacaban igualmente a la circunstancia de que hacía tiempo que el diezmo-señor no se hacía efectivo.

Aceptada la vía de la redención por parte de la Comunidad, la cantidad estipulada por Hacienda para abordarla fue de 31.515 pesetas con 55 céntimos, que se distribuiría de forma equitativa entre los distintos propietarios de las eras tomando, como siempre, el punto de referencia de lo que cada propietario abonaba en concepto del propio diezmo-señor. Se optó por acometerla al contado, pero como no todos los herederos parecían estar en condiciones de poder asumir el gasto que se les asignaba, la Comunidad se decidió igualmente a solicitar un préstamo. El prestamista, don Francisco de Varona, estableció el plazo de devolución del capital en ocho años, mientras que el tipo de interés variaría entre un 7 y un $9 \%$ anual en función de los avales y garantías que el heredero

72 ATHA. Fondos Especiales. Salineros. Caja 7. Carp. 46, f. 21 r. 
pudiese presentar ${ }^{73}$. Varona acabó aportando 11.165 pesetas y 15 céntimos, es decir, el 35,42\% del total de lo exigido para la redención. El $40 \%$ de los herederos comprometidos en ella se acogieron totalmente al préstamo, el resto abonaron su parte al contado. Por fin, el día 22 de febrero de 1906, el presidente de la Comunidad de Herederos abonó en el Banco de España el capital exigido desde el Ministerio para redimir de una vez por todas el canon del diezmo-señor y situados, que cuando menos desde el siglo XVI había regulado la distribución de las mueras entre la Comunidad y la Corona y el funcionamiento de las reales fábricas. A partir de entonces los herederos se plantearon la creación de una Compañía Anónima por acciones, al parecer sin demasiado éxito.

73 Varona se reservaba el derecho de cobrar una cantidad nunca inferior a las 250 pesetas «como saldo de cuenta» transcurrido un año a todo heredero que no cumpliese puntualmente con la devolución del capital. Por lo demás, y dado que la redención del censo debía hacerse «a favor de la Comunidad», ésta se obligaba a llevar a los tribunales a todo heredero propietario que resultase moroso con el pago del capital o los intereses. ATHA. Fondos Especiales. Salineros. Caja 19. Carp. 49, ff. 9r-10v. 